\title{
Political connections with corrupt government bureaucrats and corporate M\&A decisions: A natural experiment from the anti-corruption cases in China
}

\begin{abstract}
Using 29 recent high level anti-corruption cases in China as a natural experiment, we examine the patterns in merger and acquisition (M\&A) decisions and performance in Chinese non-state owned enterprises (non-SOEs) before and after the exogenous severing of political connections. We identify a set of listed related non-SOEs whose managers bribed or had connections, through past working and educational experience, with corrupt bureaucrats from 2005 to 2011. We document that, after the arrest of corrupt bureaucrats, corruption related nonSOEs lose their competitive advantages in the M\&A market. We observe a significant reduction in the likelihood of conducting M\&As and the ability to access local and state-owned targets for these firms. They pay a higher takeover premium and consequently have worse postM\&A performance. Our results are robust when we exclude bribing firms, and firms whose related corrupt bureaucrats are arrested within a year before the announcement of the M\&A. Furthermore, the influence of anti-corruption events varies across regions that have different levels of corruption index and industries with different levels of government support and competition. Overall, our study provides direct evidence to the question of why firms seek to establish connections with government officials through bribery or personal connections, and we reveal the benefits and costs of such connections.
\end{abstract}

Key words: Political connections, anti-corruption, M\&A, M\&A performance

JEL classification: G32; G34; G38 


\section{Introduction}

Corruption is reported as a prevalent phenomenon around the world and is becoming an increasingly important concern for companies. The literature shows that corruption may bring various benefits to corruption-related firms, such as improving their efficiency (Beck and Maher, 1986), reducing transaction costs (Cheung et al., 2012), and giving better access to external financial markets (Fan et al., 2008), thus increasing firm value (Cheung et al., 2012; Karpoff et al., 2010). It is not surprising that the benefits of corruption are more important in emerging markets, because corruption compensates for the low quality of public governance and can therefore reduce its negative effect (Meon and Sekkat, 2005). That is why firms, especially non-state owned enterprises (non-SOEs), in emerging markets have a strong incentive to offer bribes to or form connections with government officials. In other words, corruption is an important channel through which firms establish political connections, and it brings direct benefits to the firms involved. However, given the illegality of corruption, the inherent uncertainty creates costs and may offset its value-enhancing mechanisms (Bardhan, 1997; Meon and Sekkat, 2005). In particular, corruption-related firms may lose their connections with the corrupt bureaucrats after the corruption scandal is exposed, resulting in a significant political and operational risk to those firms. Therefore, an investigation into anticorruption events will enable us to better understand how political connections with corrupt government bureaucrats, through bribery or personal connections, influence corporate decisions. Moreover, an anti-corruption event is exogenous to firm decisions, which means that it could be used as a natural experiment to avoid a potential endogeneity issue (Fan et al., 2008; Cheung et al., 2012 and Fan et al., 2014).

The literature on political connections shows that, in emerging markets such as China, where the government still has controlling power over firms' access to financial resources and investment projects, politically connected managers play an important role in helping firms to 
gain access to various financial resources, such as bank loans and the equity market (Faccio et al., 2006; Fan et al., 2008; Li et al., 2008 and Liu et al., 2013). However, these conventional studies generally use the current or former working experience of managers as government officials as a measure of firms’ political connections (Chen et al., 2011; Liu et al., 2013), and implicitly conjecture that politically connected managers enable connected firms to obtain benefits from the government through rent-seeking behavior. The drawbacks of this approach are: (1) the definition of political connections suffers from an endogeneity issue, although it is controlled; (2) while it is argued that politically connected managers tend to bring benefits to connected firms by seeking rent from the government, the channel is not identified.

In this study, we hypothesize that firms establish political connections through bribery and personal connections with bureaucrats, which enables them to obtain profitable merger and acquisition (M\&A) projects in China. In order to overcome the potential endogeneity issue, this study adopts an event study approach, which employs the high-level bureaucrat corruption scandal (provincial or higher) as a natural experiment. This approach was initiated by Fan et al. (2008) to avoid the confounding factors and endogeneity problems of cross-sectional studies, and has been empirically supported by Cheung et al. (2012) and Fan et al. (2014).

In China, the arrest of high-level corrupt bureaucrats is exogenous to the firms (Fan et al., 2008). In contrast to the municipal or lower level of corruption scandals, these high-profile corruption cases are typically exposed due to political strife or other reasons that have little to do with the business of the related firms. Given the weakness of the institutional environment and legal enforcement, the personal connection is expected to be more effective than a legal contract in China. The establishment of connections with political officials by offering bribes is a common and traditional business practice. Therefore, bribe taking is unlikely to be the direct and crucial reason for the arrest of high-profile government officials in China. Moreover, although anti-corruption enforcement is waged in the name of law and accountability, the 
investigation is non-transparently operated beyond the law by a central government and partyrun agencies ${ }^{1}$. It is not difficult to see that the arrest of some high-profile bureaucrats is politically motivated, even though they are accused of bribe taking. Therefore, anti-corruption enforcement is largely exogenous for related firms: it is top down from the central government, politically motivated, and has little to do with the firms' business operations or the actual bribery (Fan et al., 2014). Moreover, the detection of corruption cases is exogenous to related firms in China. The detection of corrupt bureaucrats is usually triggered by unrelated investigations in the cases of other government officials, by voluntary informers, whistleblowers, the bureaucrats' mistresses or their political competitors, or private investigations by journalists. Cheung et al. (2012) conduct an empirical test and indicate that the detection of corruption is not related to the bribing firms.

Therefore, the exposure of corruption could serve as an exogenous shock, which unexpectedly breaks the connections between accused bureaucrats and the bribing firms. To provide a further robustness test, we identify personally connected firms, which are listed firms connected with corrupt government officials through their top managers' former working affiliations and educational experience. These personally connected firms may not necessarily actively bribe corrupt bureaucrats; rather, they establish their connection through either their former working affiliations or educational experience. Therefore, any changes in their M\&A decisions and post-M\&A performance after the anti-corruption event should not be directly driven by the event itself but by their loss of connections, which largely evades the endogeneity issue.

To conduct this natural experiment, we collected a sample of 29 corruption cases involving provincial or higher level bureaucrats in China during the period from 2005 to 2011, to investigate how the M\&A decisions and performance of corruption-related firms are influenced

\footnotetext{
${ }^{1}$ For the detailed information, please refer to the article 'The New Victims of China's War on Corruption' by The New York Times, http://cn.nytimes.com/china/20141020/c20corruption/en-us/.
} 
by the anti-corruption event compared to unrelated firms. We classify listed firms into two types: (1) corruption-related firms (related firms), which include listed firms whose senior managers or directors have bribed corrupt bureaucrats (bribing firms), and listed firms whose senior managers or directors are connected with corrupt bureaucrats, through either their former working affiliations or educational experience (personally connected firms); and (2) unrelated firms, which include firms whose senior managers or directors have neither paid bribes nor been connected with corrupt bureaucrats. We examine how related firms’ M\&A decisions and performance change, relative to these unrelated firms, after they lose their connections with the government in an anti-corruption event. We expect that, compared to unrelated firms, related firms may receive benefits from the M\&A market by obtaining more quality targets, especially when the targets are controlled by the state, or when they conduct local M\&A, which means the target firms are from the local M\&A markets which are directly controlled by their related bureaucrats. They may also obtain other benefits when they conduct M\&A, such as paying a lower M\&A premium, and thus have a better post-M\&A performance ${ }^{2}$. However, these benefits should disappear after these firms lose their connections in an anti-corruption event.

As the largest emerging market, the capital market in China provides an ideal institutional environment in which to conduct our analysis. Firstly, China is recognized as a highly corrupt country. According to the Corruption Perception Index (CPI) from Transparency International, China ranked 75 out of 182 countries around the world in $2011^{3}$. Moreover, La Porta et al. (2004) document that China is among the worst countries in terms of political freedom and the protection of property rights. The more direct evidence from the official reports of the Central

\footnotetext{
${ }^{2}$ For instance, the controlling shareholder of Thaihot Group Co (000732), Huang Qisen, is identified as a briber who bribed the former secretary-general of the CPC in Fujian province, Chen Shaoyong, who was involved in a corruption scandal and was arrested in 2008. In 2004, Mr Chen helped Mr Huang to acquire the state-owned shares of Fujian Mindong Electric Power Limited Company. In return, Mr Chen received a Patek Philippe watch as a gift from Mr Huang, which was worth 80,000 Hong Kong dollars.

${ }^{3}$ The CPI ranks countries and territories according to their perceived levels of public sector corruption. The index is ranked from the least corrupt country to the most corrupt country. For the detailed information, please refer to the CPI 2011 annual report by Transparency International, http://www.transparency.org/cpi2011/results.
} 
Commission for Discipline Inspection of the Communist Party of China records that 643,759 corruption cases were under investigation, 639,068 corruption cases were concluded, 668,429 people were punished by the administrative and Party disciplinary agencies and 24,584 people were transferred to the judicial organs for further investigations, from the end of 2007 to 2012. There were 81,391 commercial bribery cases that were under investigation, and more than 20 billion Chinese yuan were involved in these cases. This huge number of corruption cases not only provides opportunities to conduct our studies, but also reveals the importance and prevalence of having connections with government officials in China. Furthermore, the network (so-called 'Guanxi') is regarded as one of the most important and dominant factors in business operations in China, rather than formal contracts (Xin and Pearce, 1996). Under this institutional environment, the impacts of informal social connections such as political connections are enhanced.

Secondly, the Chinese government still has a great capacity to intervene directly in firms' M\&As at the various levels. For instance, while the Chinese economy has transformed from a government-controlled to a market-oriented economy, local governments still retain the right to allocate various resources through licensing, granting the right of land use and access to the capital market (Cull and Xu, 2003; Firth et al., 2009; Li et al., 2009 and Chen et al., 2011). Moreover, M\&A deals must obtain permission from local governments if they relate to a stateowned enterprise (SOE). Under these circumstances, Chinese firms will have a strong incentive to build connections with bureaucrats through bribery or hiring connected managers. These political connections will facilitate the M\&A process and also create value when they conduct M\&As. Therefore, we expect that firms which have paid bribes and formed connections with bureaucrats will have superior post-M\&A performance before the corrupt bureaucrats are arrested, but that their post-M\&A performance will decline significantly after the event. 
Lastly, in contrast to SOEs, which by nature have a close relationship with the government, non-SOEs are more likely to establish connections with the government through bribery, due to the continuing rule of the Communist Party and ideological discrimination against nonSOEs. Therefore, we expect that an anti-corruption event should have a more pronounced influence on the M\&A decisions and performance of non-SOEs compared to SOEs.

Using a sample of $383 \mathrm{M} \& \mathrm{~A}$ announcements in Chinese publicly listed non-state controlled firms (non-SOEs) from 2005 to 2011, we conducted a series of empirical tests to provide evidence for our hypotheses. Our results confirm that related firms, including bribing firms and personally connected firms, are more likely to conduct M\&As than unrelated firms before the anti-corruption events, and that the likelihood of conducting M\&As in these related firms declines significantly after the arrest of corrupt bureaucrats. The likelihood of acquiring a local target and state-owned firm decreases more significantly for related non-SOEs than for unrelated firms after the arrest of corrupt bureaucrats. Moreover, related non-SOEs pay a higher takeover premium after the breaking of their connections. Consistently, the post-M\&A performance of related non-SOEs, as measured by the short-term cumulative abnormal returns (CARs) around announcement date and long-term buy-and-hold returns, is significantly worse than that of the unrelated private firms subsequent to the arrest of the corrupt government officials. Overall, our results suggest that Chinese non-SOEs do benefit from bribing and connecting with corrupt bureaucrats, by having better access to the M\&A market and paying lower M\&A premiums, which results in a good post-M\&A performance. However, this superior performance in the M\&A market disappears when such connections are broken as a result of an anti-corruption event.

Our robustness results further show that the impact that the anti-corruption event has on postM\&A performance varies across regions and industries: the event has a greater impact on M\&A transactions in highly corrupt regions, government-supported industries and industries which 
are not very competitive. Finally, our results are robust to the M\&A deals conducted by firms with longer-term connections with government officials, and are immune to the argument that better quality firms are more likely to have political connections and be able to conduct valueenhancing M\&As.

This study contributes to the literature in the following ways. Firstly, our study extends the current literature on M\&A decisions and performance. Previous studies in this area mainly focus on the effect of firm-specific and industry factors on M\&A performance (Moeller et al., 2004; Faccio and Masulis, 2005; Dong et al., 2006; Rhodes-Kropf et al., 2005; Masulis et al., 2007; Cai and Sevilir, 2012; Ishii and Xuan, 2014). By using anti-corruption events in China as a natural experiment, which greatly alleviates the endogeneity issue, we provide direct evidence that, in emerging markets with poor shareholder protection and high levels of government intervention, public sector governance has an important influence on firms’ M\&A decisions and performance. Therefore, we add new evidence to this strand of the literature.

Our study also contributes to the literature on political connections. In particular, previous studies mainly focus on the effect of political connections on firm value and the ability to access external financial markets (Fisman, 2001; Johnson and Mitton, 2003; Khwaja and Mian, 2005). We extend these studies by investigating how political connections affect firms' M\&A transactions. More importantly, in previous studies, the firm's political connections are usually measured by managers' previous working experience in governments. Our study adopts a more direct measure of political connections: i.e. firms that form relationships with corrupt government officials either through direct bribery or by personal connections. By showing that related firms conduct more (less) M\&As, pay a (lower) higher M\&A premium, and have (better) worse post-M\&A performance before (after) the anti-corruption event, we provide direct evidence of the benefits and costs of the political connections in Chinese non-SOEs. 
The remainder of the paper is organized as follows. Section 2 develops our hypotheses. Section 3 introduces our data, sample, variables and the empirical model employed. Section 4 presents the empirical results and interpretations. Section 5 summarizes and concludes this paper.

\section{Hypothesis development}

\subsection{The arrest of corrupt bureaucrats and corporate $M \& A$ decisions}

\subsubsection{The arrest of corrupt bureaucrats and likelihood of conducting M\&As}

As discussed in the previous section, the Chinese capital market is known for its high degree of government intervention and discrimination against private firms. The government and politicians implicitly shape and control the daily operations of non-SOEs through regulations, licenses and political networks (Piotroski and Zhang, 2014). This encourages Chinese nonSOEs to establish political connections with local government officials in order to seek rents from the government and to overcome ideological discrimination. The Chinese M\&A market is characterized by a high level of intervention by the local governments and authorized government agencies. Therefore, non-SOEs have a strong incentive to bribe or connect with local government bureaucrats in exchange for obtaining better access to the M\&A market and gaining competitive advantages. However, when the related corrupt bureaucrats are under investigation or arrested, such political connections are broken. Thus, the preferential access to the M\&A market will disappear. Therefore, we predict that the likelihood of conducting M\&As for related non-SOEs will decrease significantly subsequent to the arrest of corrupt bureaucrats. Based on the above analysis, we hypothesize that:

H1a: The likelihood that related (bribing or personally connected) non-SOEs will conduct M\&A deals will significantly decrease after the arrest of corrupt bureaucrats.

\subsubsection{The arrest of corrupt bureaucrats, and the likelihood that non-SOEs will conduct local M\&As or merge with SOE targets}


As discussed above, corrupt bureaucrats help related non-SOEs to gain access to the M\&A market. However, the power of bureaucrats is often limited by geographic distance, which means that related firms will be more likely to acquire targets that are located in the jurisdictions of their connected bureaucrats. Therefore, we expect that related non-SOEs will be more likely to conduct local M\&As. However, their ability to access the local M\&A market will decrease after the arrest of corrupt bureaucrats.

As the manager and controlling shareholder of SOEs, local government has the ultimate right to make decisions and is better able to directly and easily influence the operational activities in these firms than in private firms. Moreover, due to the weak legal protection and lack of monitoring by the supervisory agencies of state-owned assets, government officials may utilize their control right over SOEs for their private benefit. Thus the related non-SOEs are more likely to obtain quality state-owned assets than are the unrelated firms. However, the breaking of connections by anti-corruption enforcement terminates their preferential treatment. We thus expect that related non-SOEs will experience a significant decline in the likelihood of acquiring a state-owned target subsequent to anti-corruption enforcement. Therefore, we hypothesize that:

H1b: The likelihood that related (bribing or personally connected) non-SOEs will acquire a local target and/or state-owned target will significantly decrease after the arrest of corrupt bureaucrats.

\subsubsection{The arrest of corrupt bureaucrats and takeover premium}

In the previous section, we argue that related non-SOEs would have a preference in accessing the M\&A market. Another possible benefit that related non-SOEs might obtain through bribery or connecting with government bureaucrats is to acquire target firms by paying a lower M\&A premium. By bribing or connecting with local bureaucrats, the acquirers may have the chance 
to learn the true value of target firms and reduce the information asymmetry in the deals. Moreover, through government intervention, the corrupt bureaucrats may even influence the managers/shareholders of the target firms to accept the offer from related firms to merge with their firms at a relatively lower price. Thus, we argue that political connections with government bureaucrats will reduce the takeover premium for related non-SOEs. However, subsequent to the arrest of corrupt local bureaucrats, related non-SOEs will lose their connections and have to pay a higher premium than before. Thus our next hypothesis is:

H1c: The takeover premium for related (bribing or personally connected) non-SOEs will significantly increase after the arrest of corrupt bureaucrats.

\subsection{The arrest of corrupt bureaucrats and post-M\&A performance}

As discussed above, by forming relationships with government bureaucrats through bribery or personal connections, non-SOEs may obtain good M\&A opportunities but pay a relatively low M\&A price, and thus their M\&A activities are more likely to be value-creating. However, after corrupt government bureaucrats are dismissed, the non-SOEs might conduct more valuedestroying M\&A activities, as they might lose the various kinds of assistance from the corrupt bureaucrats with whom they had relationships. Therefore, it is expected that related non-SOEs will have better post-M\&A performance before an anti-corruption event is announced, while such good performance should decrease after local bureaucrats are arrested. Therefore, we develop our hypothesis as follows:

H2: The post-M\&A performance of related (bribing or personally connected) non-SOEs will significantly decrease after the arrest of corrupt bureaucrats.

\section{Methodology and measurement of variables}

\subsection{Cases of bureaucratic corruption}


To test our hypotheses, we manually collected a list of corruption cases, which include Chinese bureaucrats at provincial level or higher, and identify the listed firms whose senior managers or directors have directly bribed, or had connections through past working and educational experience with, the corrupt government officials. As discussed earlier, we only focus on corruption cases involving high-level government officials (provincial level and above) to keep our study free from endogeneity issues. We employed the following process to collect the corruption cases. Firstly, we collected a list of corrupt government officers from 2005 to 2011 from the Central Commission for Discipline Inspection of the Communist Party of China, and three other government websites: people.cn, huanqiu.com and xinhua.net. These websites are sponsored by the People's Daily, which is the official newspaper of the Chinese government. We further made efforts to extend our list of corruption cases from other well-known websites in China, such as ifeng.com, sina.com.cn, and NetEase. In order to identify the bribing firms in our corruption cases, we kept only corruption cases that have been reported in detail by the Legislative Affairs Office of the State Council P. R. China or in the bulletin of the Supreme People's Procuratorate of the People's Republic of China. These resources usually report detailed information about the people who have offered bribes to corrupt bureaucrats and the firms that have been illegally assisted by corrupt bureaucrats. Ultimately, we collected 29 highlevel corruption cases from 2005 to 2011.

For all 29 of the corruption cases, we went through the reports published by the Legislative Affairs Office of the State Council P. R. China and the bulletin of the Supreme People's Procuratorate of the People's Republic of China to identify whether any of the listed firms (bribing firms) bribed the bureaucrats in question. We made further efforts to search through the above three official government news agencies and other available news services that disclose the investigation of these cases, to find out whether senior managers or directors of any of the other listed firms were involved in these corruption cases. 
To identify the personally connected firms that are connected with the corrupt bureaucrats through working or educational affiliations but have not paid bribes or been involved in the corruption scandals, we searched through firms' annual reports and initial public offer prospectuses and collected the profiles of senior managers and directors for each firm before the corruption event. Then we defined personally connected firms as those in which the firm's senior managers or directors had previous working and educational affiliations with the corrupt government officers. The unrelated firms are the remaining listed firms, which neither paid bribes to nor had connections with the corrupt bureaucrats.

Although we have made great efforts in the process of collecting corruption cases and identifying related firms, it is possible that we might have missed some related firms due to limited information. However, we have found that in China the extent of information disclosure about corruption cases involving corrupt bureaucrats, and the firms involved in these cases, is similar among all corruption cases. Therefore, any missing data are more likely to be random and less likely to influence our results. This bias would only weaken the significance level of our findings. In contrast to Fan et al. (2008), we do not limit our research to firms that are located in the corrupt bureaucrats' jurisdictions, but focus on all listed firms in the Shanghai and Shenzhen stock exchanges, in order to avoid missing any related firms. However, we have also constructed a sample that only includes firms located in the jurisdictions of the corrupt government officers. We find that our results still hold when using this latter sample. A list of the corruption events is reported in Appendix A.

\subsection{Sample}

The sample used in this paper includes the M\&A deals conducted by publicly listed non-SOEs on the Shanghai and Shenzhen stock exchanges from 2005 to 2011. We used the CSMAR China Listed Firms' M\&A Database to obtain announcement dates, information about acquiring and target firms, and M\&A financial information for completed deals in our sample 
period. We also collected other information from a series of datasets from the CSMAR database. This includes the China Stock Market Financial Statement Database from 2005 to 2011; the China Listed Firms’ Corporate Governance Research Database from 2005 to 2011; and the China stock market trading database from 2004 to 2011. The CSMAR database is one of the most important and widely used databases in research on the Chinese capital market.

Following previous studies in M\&As, we require M\&A deals to meet the following criteria. We require that the acquiring firm obtains at least $51 \%$ of the target shares, and omit M\&A deals in which the acquiring firm already holds at least $51 \%$ of the target before the deal (Malmendier and Tate, 2008). Moreover, we exclude small transactions in which the deal value is less than 1\% of the acquirer's market capitalization (Cai and Sevilir, 2012; Masulis et al., 2007). In order to make our calculation of M\&A performance free from contamination from other announcements, we further exclude M\&A announcements when the acquiring firms announce two or more M\&A deals within three months, and announcements when the acquiring firms make other announcements during our event window. We require the acquirer to have information about their annual financial statement available (three years prior to acquisition announcements and three years post these announcements) and stock return data (280 trading days prior to M\&A announcements) from CSMAR databases. Finally, we exclude those deals for which information about the acquiring or target firm, the announcement date and financial data are missing. After meeting these criteria, our final sample yields 383 M\&A cases from a total of 4,875 firm year observations.

\subsection{Measurement of variables}

\subsubsection{Corruption}

As discussed above, we define firms as having connections with the government when they have paid bribes or are connected with corrupt bureaucrats. These related firms (bribing firms 
and personally connected firms) are defined by a dummy variable 'CORRUPTION', which equals one if the firm commits bribery or is connected with a corrupt government officer. We further include a dummy variable 'POST', which equals one if the M\&A deal is conducted after the corruption event. The emphasis of this study is on the interaction term 'CORRP*POST'. This interaction term picks up changes in the related firms' M\&A decisions and performance after the corruption event, relative to those of the unrelated firms. We expected that this interaction would be significantly negatively related to post-acquisition performance and positively associated with takeover premium in non-SOEs, while it would be insignificant in SOEs.

\subsubsection{Other variables}

A series of variables are constructed to measure firms' M\&A decisions and post-M\&A performance. We first define a dummy variable ' $M \& A$ ', which is equal to one if the firm conducts an M\&A in a given year, to measure the likelihood of conducting an M\&A.

The short-term post-M\&A performance is measured by the three-, five- and 11-day post-M\&A cumulative abnormal market-adjusted stock returns (CARs). We calculate the abnormal return in the M\&A announcement period by using the standard event study methodology of Brown and Warner (1985). The estimation period is 250 trading days, which starts from 280 trading days prior to the event date for each M\&A announcement in our sample. Over this estimation period, the daily returns of firms making an M\&A announcement are regressed on the valueweighted market return on the Shanghai and Shenzhen stock exchanges. The daily abnormal return is defined as the difference between the actual daily return and market model expected daily return using the estimated factor loadings from these regression results. We cumulate the daily abnormal returns over the event windows (-1 to $1,-2$ to 2 and -5 to 5 ), to measure the abnormal performance upon M\&A announcement. The long-term performance is measured by the one-, two- and three-year buy and hold stock returns (BHARs). 
We use two variables to measure the takeover premium. 'PREMIUM1' is a relative measure defined as the total dollar premium (measured by trading value minus fair value of the target firm's equity value) relative to the fair value of the target firm's equity value. 'PREMIUM2' is defined as the natural logarithm of the dollar premium.

We expect that connected firms are more likely to conduct acquisitions that are under the corrupt bureaucrats' control. Thus, we also collect the target firms' location data and define a dummy variable (LOCAL), which equals 1 if the acquiring and target firm are located in the same province. We collect the target firms' ownership data and define a dummy variable (Target SOE), which equals 1 if the target is controlled by the state.

To conduct our regression analysis, we also include various control variables in our regression models to control for factors that may affect M\&A performance. The definitions of these variables are reported in detail in Appendix B.

\subsection{Regression model and research design}

We use the following equation as the baseline regression model to test our hypotheses:

$$
\begin{aligned}
& \text { M\&A /LOCAL/Target SOE /PREMIUM/Performance/ } \\
& \quad=\alpha_{0}+\beta_{1} \times \text { CORRUPTION }_{i, t}+\beta_{2} \times \text { POST }_{i, t}+\beta_{3} \times \text { CORP } \times \text { POST }_{i, t}+\beta_{4} \\
& \quad \times \text { Control Variables } i, t+\beta_{5} \times \text { Year Dummy }+\beta_{6} \times \text { Industry Dummy } \\
& \quad+\varepsilon
\end{aligned}
$$

In equation 1, the dependent variables are: 'M\&A' dummy variable; Local M\&A dummy variable; Target SOE dummy variable; takeover premium; and post-M\&A performance. All control variables are as defined in Appendix B. We also include a set of year and industry dummy variables to control for the year and industry fixed effects.

To examine how related firms’ M\&A decisions and post-M\&A performance change after the arrest of corrupt bureaucrats, we firstly employ our full sample to run the above regression 
model. For the robustness check, we then repeat the main regression analyses, using the sample of firms that are located in the corrupt government officers' jurisdictions. In order to eliminate the concern that our results are mainly driven by the bribing firms, we thirdly remove the bribing firms from our sample and repeat the analysis for the impact of anti-corruption events on M\&A decisions and performance for personally connected firms only. We further limit our sample period to the years before the corruption scandals are exposed, and test the question whether corrupt government officers provide benefits to related firms when they conduct M\&As. Finally, we limit our sample to those firms which have longer-term connections with corrupt government officials, to eliminate the possibility that the anti-corruption enforcements are caused by these M\&A deals.

\section{Empirical results}

\subsection{Summary statistics and univariate tests}

\subsubsection{Summary statistics}

Table 1 presents the summary statistics for our main variables. The results show that the proportion of related non-SOEs accounts for $14 \%$ of our full sample. We find that the proportion of M\&A deals conducted by related non-SOEs amounts to $21 \%$ of sample. The high proportion of related firms reveals the importance of being connected with local governments in China. For the M\&A performance of acquiring firms, our results show that the shareholders of acquiring firms earn a slightly positive return (about 3\%) around the announcements, with a relatively high long-term post-acquisition performance after conducting the acquisition deals. The proportions of local acquisitions and acquisitions of a state-owned target amount to 54\% and 12\%, respectively, out of the 383 acquisitions from 2005 to 2011 . We also find that acquiring firms are willing to pay a high premium to secure the controlling rights of the target, which is demonstrated by the positive value of PREMIUM1 (the average PREMIUM1 is 2.8, 
which means that firms pay on average 2.8 times the estimated fair value of the target). In this study, the target value is relatively small compared to that of the bidding firms, which is only about $52 \%$ of the acquirer's market value. In our sample, almost $87 \%$ of M\&As in China are completed by cash payment rather than share payment, which is much higher than in developed countries like the US. Ishii and Xuan (2014) show that purely cash deals were only about 32\% in the US from 1999 to 2007.

$<$ Table $1>$

\subsubsection{Univariate test}

The univariate test results are reported in Table 2. The difference-in-difference method is used to test the changes in M\&A characteristics before and after the corruption events. Panel A presents the results of the impact of corruption events on the likelihood of conducting M\&As. Panels B and C show the univariate test results for the effects of corruption events on the likelihood of conducting local M\&As and acquiring a state-owned target. Panel D tabulates univariate test results for the impact of a corruption event on the takeover premium. The results for the influence of corruption events on post-M\&A performance are reported in Panel E.

As shown in Panel A, we find the likelihood of related non-SOEs conducting M\&As is significantly higher than their unrelated counterparts, before the corruption scandals are exposed, while the difference becomes insignificant after the arrest of corrupt bureaucrats. Moreover, after the corruption events, related non-SOEs have a significantly reduced likelihood of conducting M\&As. Overall, the results support our hypothesis H1a.

The results in Panels B, C and D show that related non-SOEs are more likely to acquire local and state-owned firms and pay a lower takeover premium than unrelated firms, before the corruption event (1.21 vs. 2.16). Moreover, we find that after the arrest of corrupt bureaucrats, the likelihood of related non-SOEs acquiring a local and state-owned firm drops significantly, 
and the takeover premium of related non-SOEs is significantly higher than that of unrelated non-SOEs. These results reveal that related non-SOEs lose the ability to access the local M\&A market after they lose their connections with government officials, which confirms our hypotheses H1b and H1c.

In Panel $\mathrm{E}$ of Table 2, we find that the difference in post-M\&A performance between related non-SOEs and unrelated non-SOEs is significant and positive before the arrest of corrupt bureaucrats. After the corruption event, the post-M\&A performance of related non-SOEs declines significantly compared to that of unrelated firms. These findings suggest that being connected with corrupt bureaucrats results in M\&As conducted by related firms having superior performance before the event, while this outstanding performance disappears on losing their political connections after the event. The results in Panel B confirm hypothesis H2.

$<$ Table 2>

\subsection{Regression analysis}

We next conduct a regression analysis to examine whether the M\&A decisions and post-M\&A performance of related firms change after the arrest of corrupt bureaucrats, as we expect, when we control for other factors that are identified as having an influence on M\&A decisions and performance.

\subsubsection{Anti-corruption events and M\&A decisions}

\subsubsection{Anti-corruption events and the likelihood of conducting M\&As}

Our regression analysis begins by investigating the impact of the anti-corruption events on the likelihood of conducting M\&A deals. Column 1 of Table 3 presents the results. As per our expectations, the estimated coefficient of the related firms, 'CORRUPTION', is significantly positively associated with the likelihood that non-SOEs will conduct M\&As, suggesting that related non-SOEs conduct more M\&As in general. We are particularly interested in the 
interaction term 'CORP*POST', which demonstrates how the likelihood of related firms conducting M\&As changes after the arrest of corrupt bureaucrats. Our results show that the coefficient of the interaction term, 'CORP*POST', is significant and negative. The marginal effect of the arrest of corruption bureaucrats for the related firm is -0.053 . This indicates that the predicted probability that related non-SOEs conduct M\&As decreases by 5\% subsequent to the arrest of bureaucrats.

For robustness, we limit our sample to firms that are located in the corrupt bureaucrats' jurisdictions around the anti-corruption events, and the results are reported in Column 4 of Table 3. The results are consistent with our previous findings. Overall, our results in Table 3 confirm our hypothesis H1a.

\subsubsection{The impact of anti-corruption events on local acquisitions}

Columns 2 and 4 of Table 3 present the results for the effect of corruption events on the related firms' decision to conduct local M\&As. We expected that related non-SOEs would be more likely to conduct local M\&As, since the corrupt bureaucrats would have more power to influence commercial activities under their jurisdictions. From those columns, we find that related non-SOEs are more likely to conduct local M\&As than their unrelated counterparts. Given that the acquirers are more likely to take advantage of a nearby target's resources and achieve a better post-M\&A performance, this result also supports our expectations of a better post-M\&A performance in related non-SOEs. More importantly, we demonstrate that the ability of related non-SOEs to acquire a local target is weakened after the arrest of corrupt bureaucrats. Therefore, the results support our hypothesis H1b regarding acquisition decisions.

\subsubsection{The impact of anti-corruption events on the likelihood of acquiring a state-owned target}


Local government officials have the direct controlling power over state-owned assets and can easily influence decisions in SOEs. Being connected with bureaucrats, the related non-SOEs have a higher probability of obtaining quality state-owned assets. We thus expect that the related non-SOEs are more likely to acquire a state-owned target firm than unrelated firms. However, the ability to access quality state-owned targets weakens subsequent to the arrest of corrupt bureaucrats. The empirical results are tabulated in columns 3 and 6 of Table 3. We find that the coefficient of 'CORP*POST" is significantly negative for the likelihood of acquiring a state-owned target. Our results reveal that the probability of acquiring an SOE target declined $13 \%$ in related private firms subsequent to the anti-corruption enforcement.

$<$ Table 3>

Overall the results in Table 3 support our argument. The breaking of connections with local bureaucrats weakens the related non-SOEs' ability to access the M\&A market and acquire quality targets.

\subsubsection{The impact of anti-corruption events on takeover premium}

In this subsection, we investigate the effect of corruption events on takeover premium. Our aim is to shed light on whether corrupt bureaucrats help related firms in M\&A deals by avoiding overpayment to a target. Our expectation is that anti-corruption events will significantly increase the M\&A premium for related non-SOEs. The results are reported in Table 4.

The results in Table 4 show that the estimated coefficient of 'CORRUPTION' is significantly negatively associated with takeover premium. These results confirm that related non-SOEs in general pay less to the target in M\&As. In addition, the coefficient of the interaction term, 'CORP*POST', is significantly and positively related to the takeover premium whether we use all listed firms or firms located in the bureaucrats' jurisdictions in our tests. This result reveals 
that the capacity of related firms to avoid overpaying in M\&As diminishes substantially after the anti-corruption event.

In columns 2 and 4 of Table 4 we repeat our regression analysis by replacing the dependent variable as the natural logarithm of the $M \& A$ premium. The regression results are consistent with our previous findings.

$<$ Table 4>

Overall, our results in Table 4 demonstrate that, by paying bribes or connecting with corrupt bureaucrats, related non-SOEs can avoid overpaying in acquisitions, while this capacity will be weakened following the anti-corruption events. These results also support our argument that related firms will have better performance in acquisitions, because paying too high a price for a target is the major reason why acquirers lose in M\&As (Cai and Sevilir, 2012). Thus the results in Table 4 are consistent with our hypothesis H1c.

\subsubsection{Anti-corruption events and post-M\&A performance}

Previous results show that anti-corruption events significantly affect the M\&A decisions of related non-SOEs. However, it is not clear whether these firms will have a better M\&A performance by bribing and connecting with corrupt bureaucrats, and how anti-corruption events may change this relationship. Tables 5 and 6 present the regression results for the impact of anti-corruption events on the short-term and long-term post-M\&A performance, respectively.

Table 5 shows that the estimated coefficient of 'CORRUPTION' is significantly positively associated with post-M\&A performance, which is measured by the three-, five- and 11-day cumulative abnormal market adjusted return (CARs). More importantly, we find that the estimated coefficients of the interaction term between the related non-SOE dummy and the post corruption events dummy are consistently negative and are significant in both economic magnitude and statistical significance. Specifically, our result suggests that connection with 
corrupt bureaucrats increases the related non-SOEs' three-day CARs by 5\% before the arrest of the corrupt bureaucrats, compared with the sample average of 3\%. However, non-SOEs receive $7 \%$ (the sum of 0.051 and -0.119 ) worse market reactions subsequent to the anticorruption enforcement, which is about a $300 \%$ decrease in their short-term announcement return. These results reveal that the post-M\&A performance of related non-SOEs is substantially worse after they lose their connections with government bureaucrats in the anticorruption event.

The results of long-term post-M\&A performance in Table 6 confirm our short-term post-M\&A performance results. We find that, after the arrest of corrupt bureaucrats, related non-SOEs' post-M\&A long-term performance is significantly worse than before. The two-year buy and hold abnormal returns reduce by 73\% subsequent to the arrest of bureaucrats in the corruptionrelated non-SOEs.

We repeat the above regression analyses by using the sample for the corrupt bureaucrats' jurisdiction, and the results are reported in columns 4 to 6 of Tables 5 and 6 . These results are consistent with the previous findings. Overall, these results confirm our hypothesis H2.

$<$ Table 5>

$<$ Table 6>

\subsection{Excluding the effect of bribing firms}

So far, we have provided substantial evidence to support our main hypotheses, that related nonSOEs conduct fewer M\&As, are less likely to acquire local and state-owned targets, pay a higher M\&A premium, and have worse post-M\&A performance, after they lose their connections in an anti-corruption event. However, it is possible that the previous results are mainly driven by the bribing firms: that the diminished performance in M\&A transactions in related non-SOEs is driven by the bribery cases rather than loss of political connections. 
Therefore, it would be helpful to investigate whether deteriorated M\&A decisions and performance subsequent to the anti-corruption enforcement can be explained by the breaking of political connections alone. In order to do so, we repeat the above regressions using only the personally connected non-SOEs. These results are reported in Table 7.

In Table 7, we present a set of regressions to test the impact of corruption events on the personally connected firms' M\&A decisions (Panel A), takeover premium (Panel B), and the short-term and long-term post-M\&A market performance (Panels C and D). In this set of regressions, as bribing firms are excluded, the dummy variable 'CORRUPTION' is defined as being one where a firm's senior managers or directors were a family member of, or have had previous work and education affiliations with, the corrupt government officers, but did not bribe them. Therefore, these personally connected non-SOEs only gain their connections by chance. From the regression results reported in Table 7, we find that the estimated coefficient of the interaction term, 'CORP*POST', is statistically significantly and negatively associated with the likelihood of conducting M\&As, the probability of acquiring a local target and SOE target, and post-M\&A performance, while significantly and positively associated with the takeover premium. These results demonstrate that, by losing political connections with the corrupt bureaucrats, personally connected non-SOEs will conduct fewer M\&As, pay a higher premium, be less likely to acquire local targets and state-owned firms, and lose their preferential performance in the deals. All of these results confirm our previous findings. As a robustness check, we repeat the above regression models for the sample that only includes listed firms in the corrupt bureaucrats' jurisdictions. The results are also consistent with the above findings; but, in order to save space, we do not report these results. To provide more robust results, we also limit our sample to those firms that have acquisition deals before and after the corruption event, and similar results are found; the results also being unreported, to save space. 
Overall, the results in this section confirm our main hypotheses that an anti-corruption event has a significant impact on the corporate M\&A decisions of Chinese non-SOEs, in that related non-SOEs conduct fewer M\&As, especially local M\&As and state-owned targets, pay a higher M\&A premium, and the M\&As conducted by related non-SOEs have worse post-M\&A performance after the arrest of corrupt bureaucrats. Our results hold even when the firms have connections but do not bribe the corrupt bureaucrats, suggesting that the diminished M\&A performance in related non-SOEs is not solely caused by the corruption events, but is a result of losing political connections with these corrupt bureaucrats.

\subsection{Alternative interpretation}

Although previous sections provide solid evidence for the impact of corruption events on the M\&A decisions of related firms, these results could have another interpretation. After the arrest of corrupt bureaucrats, the market and regulatory government agencies will have detailed information about the connected firms and bribers. Because of concerns about their reputation, the shareholders of quality target firms may refuse offers from related firms and government agencies may not be willing to approve M\&A applications from related firms. Moreover, external financial markets may also refuse to provide financial support to these firms with bad reputations. Therefore, the lower likelihood of conducting M\&As and weaker post-M\&A performance subsequent to the anti-corruption event may not be driven by the loss of political connections, but by a bad reputation.

To rule out the alternative interpretation, we further examine whether connections with corrupt government bureaucrats provide benefits to related firms in M\&As before the arrest of these bureaucrats (before our event). To conduct this test, we repeat all our regression analyses but limit our sample period to the years before the corruption scandal erupted. We regress our main 
dependent variables on the related firm dummy variable 'CORRUPTION', and control for other independent variables. We expect that related firms will have a high probability of conducting M\&As, be more likely to conduct local M\&A deals, pay a lower M\&A premium, and have better post-M\&A performance before the anti-corruption event. These results are reported in Table 8.

As shown in Table 8, we find that the estimated coefficient of 'CORRUPTION' is significantly and positively associated with the likelihood of conducting M\&As, the chances of conducting local M\&As and acquiring a state-owned target (Panel A), and short-term and long-term postM\&A market performance (Panels C and D), while the estimated coefficient of 'CORRUPTION' is significantly negatively related to takeover premium in non-SOEs in Panel B. All of these results are consistent with our expectations and support our previous arguments. Overall, these results suggest that related non-SOEs are able to obtain various benefits from the corrupt bureaucrats before the corruption event. Therefore, the poorer acquisition performance subsequent to the corruption event is not entirely caused by the alternative interpretation about concern for reputation.

$<$ Table 8>

\subsection{Robustness tests for the corruption scandals}

In this study, we argue that the arrest of corrupt bureaucrats is a natural experiment and exogenous to the firms’ M\&A decisions and performance. However, the potential issue for this argument is that the firms may actively bribe government officials when they plan to conduct M\&As. Therefore, it is unclear whether their political connections lead to quality M\&A deals. To rule out the potential explanation that firms may pay bribes to conduct M\&A projects, we exclude M\&A deals which are conducted by related firms that bribe bureaucrats within a year before the announcement of the M\&A, and conduct an empirical analysis based on the sample 
of M\&As conducted by related firms with longer-term connections with local government officials before the event date, which are firms that build their connections with corrupt bureaucrats one year, two years and three years before the announcement of these M\&As. The rationale is that longer-term relationships are less likely to be built temporarily in order to facilitate the M\&As. We expect that the results are consistent with our previous findings, after excluding the deals conducted by related firms with shorter-term connections.

As shown in Table 9, we find that the estimated coefficients of the interaction term 'CORP*POST' are significantly and negatively related to the post-M\&A performance in all subsamples. These results indicate that the related non-SOEs have significantly worse postM\&A performance than those unrelated non-SOEs subsequent to the arrest of corrupt government officials when the connections are established one year (columns 1 to 3), two years (columns 4 to 6) and three years (columns 7 to 9) before the announcement of these M\&As. Therefore, the results are consistent with our previous findings and do not support the alternative explanation that the purpose of bribing and connecting with government officials is to conduct future M\&As.

$<$ Table 9>

Another potential issue for our previous findings is that profitable firms are able to conduct more value-enhancing M\&As. At the same time, they can afford the cost of bribing local government officials and are more likely to build political connections. To rule out this potential interpretation in our results, we partition our sample by the sample median value of a firm's return on equity (ROE) and Tobin's Q. We define quality firms as those firms that have higher ROE or Tobin’s Q. If our results can be explained by the above interpretation, we would expect that the significantly negative relationship between the interaction term "CORP*POAT' and post-M\&A performance in non-SOEs can only be observed in the subsample of highquality firms. From Table 10, we find that the estimated coefficients of 'CORP*POST' are 
both significantly and negatively associated with the post-M\&A performance in both low and high-quality firms which are measured by the ROE and Tobin's Q. Therefore, our results are immune from the above potential interpretation. Overall, the results presented in Tables 9 and 10 indicate that the arrest of corrupt bureaucrats serves as a natural experiment and is exogenous to the related firms.

$<$ Table 10>

\subsection{Additional tests}

In order to provide additional evidence for our results, we further conduct the following tests: (1) we investigate whether the impact of anti-corruption events on corporate M\&A decisions and performance differs between different regions and industries. China is characterized by great variation in terms of political and economic development in different regions and industries. In particular, there is great variation in terms of corruption in different provinces; and the level of government intervention in industry development and market competition also differs from province to province. Such variations provide us with an ideal setting to investigate whether corruption events have a different impact on corporate M\&A decisions and the performance of related non-SOEs across different regions and industries. (2) Corrupt government officials are expected to have stronger and more direct control over the SOE target. We reveal that the likelihood that related non-SOEs will acquire SOE targets decreases significantly subsequent to the arrest of corrupt government officials, compared to that of unrelated non-SOEs. In this section, we further test whether the effect of the arrest of corrupt bureaucrats on M\&A performance differs depending on whether the target is an SOE or a nonSOE. (3) In addition to preferential access to the M\&A market, corrupt government officials may help related non-SOEs finance their investment, while anti-corruption enforcement diminishes their financial competitive advantage in M\&As. We thus investigate whether related non-SOEs are less likely to finance their M\&As by external funds subsequent to the 
exposure of corruption scandals. (4) M\&As are a specific type of corporate investment, and so we further investigate how an anti-corruption event may impact on corporate investment policy and investment efficiency in general.

\subsubsection{The impact of anti-corruption events on corporate M\&A performance across regions and industries}

We first examine the effect of anti-corruption events on corporate M\&A performance in regions with different levels of corruption. As expected, related non-SOEs tend to obtain benefits from their related government bureaucrats through bribery or connecting before the event, and such benefits tend to disappear after the event, so it is further expected that the M\&A performance of related non-SOEs should decrease more for firms operating in regions with high levels of corruption. To conduct this test, we collected the number of corruption cases from the Procuratorial Yearbook of China for each province from 2005 to 2011. Then we collected the number of government officials in each province who work in the departments that are related to public administration and social security from the China Statistical Yearbook and China Population and Employment Statistics Yearbook from 2005 to 2011. Then we scaled the number of corruption cases in each province by the number of government officials who work in the departments that are related to public administration and social organization. We define this ratio as the provincial corruption index. This index shows the level and importance of corruption in each province. The higher the corruption index the more severe the corruption is in a province. We thus rank the level of corruption in different provinces according to the provincial corruption index. Then we divide our non-SOE sample into two subsamples, nonSOEs in regions with a high (low) corruption index; and conduct regressions on the effect of anti-corruption events on M\&A decisions and performance in the two subsamples separately, and repeat our regressions on the effect of anti-corruption events on the post-M\&A performance of non-SOEs using the two subsamples. Table 11 presents our regression results. 
Not surprisingly, our results show that the M\&A performance of related non-SOEs operating in highly corrupt regions (regions with a high corruption index) decreases significantly more than the subsample of related non-SOEs operating in less corrupt regions (regions with a low corruption index), which supports our expectation.

$<$ Table 11>

We also expect that the influence of anti-corruption events on the post-M\&A performance of corruption-related non-SOEs will be more pronounced if these firms operate in governmentsupported industries and industries with less market competition. This is, firstly, because government-supported industries are usually subject to more direct intervention by local government officials. In particular, the Five-Year Plan is an important channel through which government intervention operates in industry development in China. These supported industries in each plan can conveniently obtain various kinds of support from the local or central government. Given that local government bureaucrats have the right to decide which firms within the supported industries are eligible to receive government support, such as tax refunds and preferential treatment in conducting M\&As, the related non-SOEs within the supported industries are more likely to obtain government support and receive more benefits than their unrelated counterparts. Secondly, another channel through which the government intervenes in industries is the issuing of licenses to firms that permit them to enter into these restricted industries. This creates some industries with very low market competition because of the high level of government restrictions and the scarcity of licenses. At the same time, other industries are highly competitive because firms are able to freely access these markets. Having connections with the government through bribery or connecting with bureaucrats may help related non-SOEs gain access to certain restricted industries through M\&As, but such benefits may disappear after firms lose such connections. 
We therefore divide our non-SOEs into two pairs of subsamples: (1) government-supported industries versus non-government-supported industries, according to whether the firm operates in a supported industry outlined in the $11^{\text {th }}$ five-year plan in a particular year; (2) less competitive industries versus highly competitive industries according to industry competition. Then we repeat our regressions on the effect of anti-corruption events on M\&A performance, using the two pairs of subsamples.

Panels A and B of Table 12 present the regression results. As expected, the empirical results support our expectation and suggest that our main results are robust.

$<$ Table 12>

\subsubsection{Anti-corruption events, type of target controlling shareholder and post-M\&A performance}

In this section, we investigate whether the arrest of corrupt government officials has a different effect on the M\&A performance of related non-SOEs depending on whether the target is an SOE or a non-SOE. Since corrupt bureaucrats often have stronger and more direct control over state-owned assets, they can sell quality SOEs to related non-SOEs, and force the SOE shareholders and managers to accept offers from related non-SOEs. There is anecdotal evidence that state-owned assets are leaked to privately controlled firms (Calomiris et al., 2010 and Chen et al., 2008). However, the breaking of such connections after the arrest of corrupt government officials would terminate their superior performance in acquiring SOE targets. We thus expect that the reduction in post-M\&A performance of related non-SOEs will be larger if the M\&A involves an SOE target. The results in Table 13 support this argument. We find the impact of the arrest of corrupt bureaucrats is stronger if the deal involves a state-owned target firm. Our results in columns 3 and 4 indicate that the post-M\&A performance of related nonSOEs is $17 \%$ lower if they acquire an SOE target after the arrest of corrupt bureaucrats. 
$<$ Table 13>

\subsubsection{Anti-corruption events and financing method}

In this section, we investigate whether related non-SOEs' superiority in financing M\&As, compared to that of unrelated non-SOEs, is weakened subsequent to the arrest of corrupt bureaucrats. The empirical results are presented in Table 14. We define the dependent variable as equal to 1 if the M\&A is financed by external funds, such as a bank loan, or the issuing of corporate bonds or shares, and 0 otherwise. The empirical results in Table 14 support our above argument. The probability that an M\&A will be financed by external funds decreases by $11 \%$ in related non-SOEs after the arrest of corrupt bureaucrats.

$<$ Table 14>

\subsubsection{Anti-corruption events, corporate investment and efficiency}

In the previous sections, we show that related non-SOEs are able to obtain various benefits when conducting M\&As, such as better opportunities to access the M\&A market, paying a lower M\&A premium, being more likely to acquire a local target and having a better postM\&A performance, before the corruption event, but that all those benefits attenuate after the government bureaucrats are arrested. However, we still do not know how the anti-corruption event impacts on corporate investment policy and investment efficiency. In order to provide a full picture for our study, we further examine the impact of corruption events on firms' investment and the investment efficiency of Chinese non-SOEs from 2005 to 2011. Because of the loss of connection with local governments as a result of the anti-corruption event, related non-SOEs lose their preferential access to the investment market and superior ability to obtain better investment projects. Therefore, we expect that related non-SOEs will have a significant reduction in their capital expenditure and investment efficiency after the arrest of corrupt bureaucrats. Tables 15 and 16 report the empirical results. 
In Table 15, corporate investment is measured by the variable 'CAPEXTA', which is cash payments for fixed assets, intangible assets and other long-term assets from the cash flow statement, less the cash receipts from selling these assets scaled by the total assets. We find that the interaction term 'CORRUPTION $\mathrm{t}-1$ *POST $\mathrm{t}-1$ ' is significantly and negatively associated with corporate investment in non-SOEs in both the full sample and the bureaucrats' jurisdiction sample, and our results hold when we exclude bribing firms from our sample.

$<$ Table 15 $>$

In Table 16, corporate investment efficiency is measured by the sensitivity of corporate investment and investment opportunity (Tobin’s Q). Not surprisingly, our results show that the investment efficiency of related non-SOEs decreases significantly after an anti-corruption event.

$<$ Table 16>

Overall, our robustness results provide further evidence that the impact of corruption events on corporate M\&A performance is greater in highly corrupt regions, and in government-supported and less competitive industries. We also demonstrate that the anti-corruption event has a negative effect on corporate investment and investment efficiency. All these results support our main argument that, by bribing or connecting with local government bureaucrats, nonSOEs are able to obtain various benefits when conducting M\&As, while they lose all these benefits when the related government official is arrested in an anti-corruption event.

\subsection{The impact of anti-corruption events on M\&A performance in SOEs}

In this section, we investigate the impact of anti-corruption events on the post-M\&A performance of SOEs. In contrast to SOEs, the profit maximization motive leads non-SOEs in China to seek and maintain political connections only if the benefits from connection can offset its costs. However, the naturally close relationship between SOEs and government reduces the 
benefits to be obtained from bribing corrupt government officials and weakens the incentive of SOEs to seek rent from local governments. More importantly, it may be more costly to maintain political connections with local governments in SOEs than in non-SOEs. In line with the 'grabbing hand' theory, it is argued that political connections are the channel through which local governments exert intervention over listed SOEs for social objectives. Furthermore, managers may utilize their control over listed SOEs for their own purposes. The empirical results reveal that political connections cost firms by reducing investment efficiency, post-IPO performance and increasing social costs (Fan et al., 2007; Chen et al., 2011 and Fisman and Wang, 2015). Since the benefits of bribing the local government may be offset by additional costs from increased government interventions in SOEs, we expect that bribing corrupt government officials will not enhance the post-M\&A performance of SOEs, and that we will not observe significant changes in their post-M\&A performance after the arrest of these bureaucrats. The empirical results are presented in Table 17. As expected, we find that related SOEs are not observed to have a higher post-M\&A performance than unconnected counterparties. Moreover, the arrest of corrupt bureaucrats does not have a significant effect on the M\&A performance of SOEs.

$<$ Table 17>

\section{Conclusion}

This study examines how firms' relationships with government bureaucrats, through bribery or personal connections, have an impact on corporate M\&A decisions and performance in Chinese listed firms. Using cases of corrupt Chinese bureaucrats as a natural experiment, we manually collected corruption scandals involving high-level (provincial level or higher) Chinese government officials and identified the listed firms that bribed or connected with these bureaucrats. We find that related (bribing or personally connected) non-SOEs are able to obtain various benefits, such as having better access to the M\&A market, paying a lower M\&A 
premium, and gaining better access to local and state-owned targets when conducting M\&As, resulting in a better post-M\&A performance, before the corruption scandals are exposed. However, all these benefits attenuate subsequent to the arrest of the corrupt bureaucrats in an anti-corruption event. We further provide evidence that the impact of the anti-corruption event on the corporate M\&A decisions and performance of non-SOEs is greater in regions with a high corruption index, and in industries with government support and less market competition. The anti-corruption event is also identified as having a negative effect on the corporate investment and investment efficiency of related non-SOEs. Our results are also robust for various alternative interpretations.

Overall, our findings suggest that in emerging markets with a high level of government intervention and ideological discrimination against non-SOEs, political connections, through bribery or personally connecting with government bureaucrats, have a great influence on M\&A decisions and post-M\&A performance in non-SOEs. This provides direct evidence for the importance of country level institutional factors on the determination of firms' M\&A decisions and post-M\&A performance, without being influenced by the endogeneity of political connections. In particular, we document that firms in emerging markets tend to establish connections with the government through bribery and connecting with government officials specifically to maximize shareholder value, but at the same time such connections create risks for shareholders when the connections are lost. 


\section{References}

Bardhan, P., 1997, Corruption and development: A review of issues, Journal of Economic Literature, 35, 1320-1346.

Beck, P. J. and Maher, M. W., 1986, A comparison of bribery and bidding in thin markets, Economics Letters, 20, 1-5.

Brown, S. J., and Warner, J. B., 1985, Using daily stock returns: the case of event studies, Journal of Financial Economics, 14, 3-31.

Cai, Y. and Sevilir, M., 2012, Board connections and M\&A transactions, Journal of Financial Economics, 103, 327-349.

Calomiris, C.W., Fisman, R. and Wang, Y., 2010, Profiting from government stakes in a command economy: Evidence from Chinese asset sales, Journal of Financial Economics, 96, 399-412.

Chen, C.J., Li, Z., Su, X. and Sun, Z., 2011, Rent-seeking incentives, corporate political connections, and the control structure of private firms: Chinese evidence, Journal of Corporate Finance, 17, 229-243.

Chen, G., Firth, M., Xin, Y. and Xu, L., 2008, Control transfers, privatization, and corporate performance: efficiency gains in China's listed companies, Journal of Financial and Quantitative Analysis, 43, 161-190.

Chen, S., Sun, Z., Tang, S. and Wu, D., 2011, Government intervention and investment efficiency: Evidence from China, Journal of Corporate Finance, 17, 259-271.

Cheung, Y. L., Rau, P. R. and Stouraitis, A., 2012, How much do firms pay as bribes and what benefits do they get? Evidence from corruption cases worldwide, working paper, National Bureau of Economic Research. 
Cull, R. and Xu, L., 2003, Who gets credit? The behavior of bureaucrats and state banks in allocating credit to Chinese state-owned enterprises, Journal of Development Economics,71, 533-559.

Dong, M., Hirshleifer, D., Richardson, S. and Teoh, S.H., 2006. Does investor misvaluation drive the takeover market? Journal of Finance, 61, 725-762.

Faccio, M. and Masulis, R.W., 2005, The choice of payment method in European mergers and acquisitions, Journal of Finance, 60, 1345-1388.

Faccio, M., Masulis, R.W, and McConnell, J.J., 2006, Political connections and corporate bailouts, The Journal of Finance, 61, 2597-2635.

Fan, J.P.H., Guan, F., Li, Z. and Yang, Y.G., 2014, Relationship networks and earnings informativeness: Evidence from corruption cases, Journal of Business Finance \& Accounting, 41, 831-866.

Fan, J.P.H., Rui, O.M. and Zhao, M., 2008, Public governance and corporate finance: Evidence from corruption cases, Journal of Comparative Economics, 36, 343-364.

Fan, J.P.H., Wong, T.J. and Zhang, T., 2007, Politically connected CEOs, corporate governance, and post-IPO performance of China’s newly partially privatized firms, Journal of Financial Economics, 84, 330-357.

Fisman, R., 2001, Estimating the value of political connections, American Economic Review, 91, 1095-1102.

Fisman, R., and Wang, Y., 2015, The mortality cost of political connections, Review of Economic Studies, 82, 1346-1382.

Firth, M., Lin, C., Liu, P. and Wong, S.M.L., 2009, Inside the black box: bank credit allocation in China's private sector, Journal of Banking and Finance, 33, 1144-1155. 
Ishii, J. and Xuan, Y., 2014, Acquirer-target social ties and merger outcomes, Journal of Financial Economics, 112, 344-363.

Johnson, S. and Mitton, T., 2003, Cronyism and capital controls: evidence from Malaysia, Journal of Financial Economics, 67, 351-382.

Karpoff, J.M., Lee, D.S., Martin, G.S., 2010, Bribery: Business as usual?, working paper, University of Washington.

Khwaja, A. and Mian, A., 2005, Do lenders favor politically connected firms? Rent provision in an emerging financial market, The Quarterly Journal of Economics, 120, 1371-1411.

La Porta, R., Lopez-de-Silanes, F., Pop-Eleches, C. and Shleifer, A., 2004, Judicial check and balances, Journal of Political Economy, 112, 445-470.

Li, H., Meng, L., Wang, Q. and Zhou, L., 2008, Political connections, financing and firm performance: evidence from Chinese private firms, Journal of Development Economics, 87, 283-299.

Li, K., Yue, H. and Zhao, L., 2009, Ownership, institutions, and capital structure: evidence from China, Journal of Comparative Economics, 37, 471-490.

Liu, Q., Tang, J. and Tian, G.G., 2013, Does political capital create value in the IPO market? Evidence from China, Journal of Corporate Finance, 23, 395-413.

Masulis, R.W., Wang, C., and Xie, F., 2007, Corporate governance and acquirer returns, Journal of Finance, 62, 1851-1899.

Meon, P., G. and Sekkat, K., 2005, Does corruption grease or sand the wheels of growth?, Public Choice, 122, 69-97.

Moeller, S.B., Scholingmann, F.P. and Stulz, R.M., 2004, Firm size and the gains from acquisitions, Journal of Financial Economics, 73, 201-228. 
Malmendier, U. and Tate, G., 2008, Who makes acquisitions? CEO overconfidence and the market’s reaction, Journal of Financial Economics, 89, 20-43.

Piotroski, J. D., \& Zhang, T. (2014). Politicians and the IPO decision: The impact of impending political promotions on IPO activity in China. Journal of Financial Economics, 111, 111-136. Rhodes-Kropf, M., Robinson, D.T. and Viswanathan, S., 2005, Valuation waves and merger activity: The empirical evidence, 77, 561-603.

Xin, K.l., and Pearce, J.l., 1996, Guanxi: connections as substitutes for formal institutional support, Academy of Management Journal, 39, 1641-1658. 
Table 1 Summary statistics

\begin{tabular}{|c|c|c|c|c|c|c|}
\hline Variables Name & Count & Mean & St. Dev. & $25 \%$ & $50 \%$ & $75 \%$ \\
\hline CORRUPTION & 4918 & 0.135 & 0.342 & 0.000 & 0.000 & 0.000 \\
\hline POST & 4918 & 0.542 & 0.498 & 0.000 & 1.000 & 1.000 \\
\hline MA & 4918 & 0.080 & 0.271 & 0.000 & 0.000 & 0.000 \\
\hline JURISDICTION & 4918 & 0.782 & 0.413 & 1.000 & 1.000 & 1.000 \\
\hline SIZE & 4918 & 21.055 & 1.127 & 20.434 & 21.010 & 21.693 \\
\hline $\mathrm{Q}$ & 4918 & 2.017 & 1.441 & 1.189 & 1.525 & 2.204 \\
\hline OPCFTA & 4918 & 0.031 & 0.207 & -0.009 & 0.037 & 0.084 \\
\hline LEVERAGE & 4918 & 0.439 & 0.241 & 0.245 & 0.434 & 0.605 \\
\hline САРЕХTA & 4918 & 0.056 & 0.061 & 0.012 & 0.040 & 0.085 \\
\hline SEO & 4918 & 0.123 & 1.297 & 0.000 & 0.000 & 0.000 \\
\hline AGE & 4918 & 6.510 & 5.440 & 1.000 & 6.000 & 11.000 \\
\hline BOARDSIZE & 4918 & 8.668 & 1.666 & 8.000 & 9.000 & 9.000 \\
\hline BOARDIND & 4918 & 0.366 & 0.052 & 0.333 & 0.333 & 0.400 \\
\hline OWNERSHIP & 4918 & 0.060 & 0.134 & 0.000 & 0.000 & 0.029 \\
\hline ROE & 4698 & 0.074 & 0.109 & 0.040 & 0.078 & 0.122 \\
\hline Local M\&As & 383 & 0.543 & 0.499 & 0.000 & 1.000 & 1.000 \\
\hline Target SOE & 383 & 0.120 & 0.326 & 0.000 & 0.000 & 0.000 \\
\hline PREMIUM1 & 157 & 2.847 & 6.364 & -0.018 & 0.000 & 0.333 \\
\hline PREMIUM2 & 157 & 23.049 & 0.080 & 23.026 & 23.026 & 23.027 \\
\hline CAR $(-1,1)$ & 383 & 0.028 & 0.117 & -0.022 & 0.009 & 0.050 \\
\hline CAR $(-2,2)$ & 383 & 0.032 & 0.115 & -0.029 & 0.015 & 0.067 \\
\hline $\operatorname{CAR}(-5,5)$ & 383 & 0.032 & 0.157 & -0.035 & 0.012 & 0.086 \\
\hline BHAR1 & 370 & 0.264 & 0.818 & -0.118 & 0.066 & 0.411 \\
\hline BHAR2 & 268 & 0.460 & 0.828 & -0.049 & 0.289 & 0.695 \\
\hline BHAR3 & 191 & 0.863 & 1.228 & 0.138 & 0.492 & 1.361 \\
\hline External Financing & 338 & 0.107 & 0.309 & 0.000 & 0.000 & 0.000 \\
\hline RELATIVE SIZE & 383 & 0.520 & 2.127 & 0.009 & 0.024 & 0.077 \\
\hline CASH PAYMENT & 383 & 0.872 & 0.334 & 1.000 & 1.000 & 1.000 \\
\hline $\begin{array}{l}\text { Connection established } \\
\text { one year before }\end{array}$ & 383 & 0.984 & 0.124 & 1.000 & 1.000 & 1.000 \\
\hline $\begin{array}{l}\text { Connection established } \\
\text { two years before }\end{array}$ & 383 & 0.974 & 0.160 & 1.000 & 1.000 & 1.000 \\
\hline $\begin{array}{l}\text { Connection established } \\
\text { three years before }\end{array}$ & 383 & 0.966 & 0.181 & 1.000 & 1.000 & 1.000 \\
\hline Corruption Index & 383 & 0.511 & 0.500 & 0.000 & 1.000 & 1.000 \\
\hline Government Support & 383 & 0.198 & 0.399 & 0.000 & 0.000 & 0.000 \\
\hline
\end{tabular}


Table 2 Univariate tests

'Related Firms' ('Unrelated Firms') represents firms that have (have not) bribed or connected with local government officials. 'Before' and 'After' represent the period before and after the arrest of corrupt bureaucrats, respectively. The definitions of variables are detailed in Appendix B.

\begin{tabular}{|c|c|c|c|c|c|c|}
\hline & Related Firms & & Unrelated firms & & Difference test & \\
\hline & Mean & Median & Mean & Median & $\mathrm{t}$ value & $\mathrm{z}$ value \\
\hline \multicolumn{7}{|c|}{ Panel A The likelihood of conducting mergers and acquisitions } \\
\hline Before & 0.157 & - & 0.064 & - & $0.093^{* * *}$ & - \\
\hline \multirow[t]{2}{*}{ After } & 0.096 & - & 0.079 & - & 0.017 & - \\
\hline & $0.061^{* *}$ & - & $-0.015^{*}$ & - & $0.076^{* * *}$ & - \\
\hline \multicolumn{7}{|c|}{ Panel B The likelihood of conducting local acquisitions } \\
\hline Before & 0.809 & - & 0.476 & - & $0.333 * * *$ & - \\
\hline \multirow[t]{2}{*}{ After } & 0.471 & - & 0.534 & - & -0.063 & - \\
\hline & $0.338 * * *$ & - & -0.058 & - & $0.396 * * *$ & - \\
\hline \multicolumn{7}{|c|}{ Panel C The likelihood of acquiring SOE targets } \\
\hline Before & 0.361 & - & 0.089 & - & $0.272^{* * *}$ & - \\
\hline \multirow{2}{*}{ After } & 0.030 & - & 0.096 & - & -0.066 & - \\
\hline & $0.331^{* * *}$ & & -0.007 & - & $0.338 * * *$ & - \\
\hline \multicolumn{7}{|c|}{ Panel D Takeover premium } \\
\hline Before & 1.213 & 0.000 & 2.155 & 0.000 & -0.942 & 0.000 \\
\hline \multirow[t]{2}{*}{ After } & 7.416 & 0.000 & 2.912 & 0.000 & $4.504^{* *}$ & $0.000 *$ \\
\hline & $-6.203 * * *$ & $0.000 *$ & -0.757 & 0.000 & $-5.446 * *$ & \\
\hline \multicolumn{7}{|c|}{ Panel E The short term post-M\&A performance } \\
\hline \multicolumn{7}{|c|}{ CAR $(-1,+1)$} \\
\hline Before & 0.086 & 0.027 & 0.027 & 0.011 & $0.059 * *$ & $0.016^{*}$ \\
\hline \multirow[t]{2}{*}{ After } & -0.02 & -0.001 & 0.021 & 0.009 & $-0.041^{* * *}$ & $-0.010 * * *$ \\
\hline & 0.106 & 0.028 & 0.006 & 0.002 & $0.100 * * *$ & \\
\hline \multicolumn{7}{|c|}{ CAR $(-2,+2)$} \\
\hline Before & $0.09 * *$ & $0.039 * * *$ & 0.03 & 0.005 & $0.060 * * *$ & $0.034^{* * *}$ \\
\hline \multirow[t]{2}{*}{ After } & -0.029 & -0.021 & 0.031 & 0.021 & $-0.060 * * *$ & $-0.042 * * *$ \\
\hline & $0.119 * * *$ & $0.06^{* * *}$ & -0.001 & -0.016 & $0.120 * * *$ & \\
\hline \multicolumn{7}{|c|}{ CAR $(-5,+5)$} \\
\hline Before & 0.042 & 0.066 & 0.033 & 0.003 & 0.009 & $0.063 *$ \\
\hline \multirow[t]{2}{*}{ After } & -0.046 & -0.02 & 0.044 & 0.014 & $-0.09 * * *$ & $-0.034 * * *$ \\
\hline & $0.088^{* *}$ & $0.086^{* * *}$ & -0.011 & -0.011 & $0.099 * *$ & \\
\hline
\end{tabular}


Table 3 Regression results for the impact of corruption events on M\&A decisions

This table presents logistic regression results for the impact of corruption events on M\&A decisions. 'FULL' includes all listed firms in the Shenzhen and Shanghai stock exchanges and 'JURISDICTION' only includes firms under corrupt bureaucrats' jurisdictions. The dependent variable 'M\&A' is binary where 1 signifies that the firm makes at least one merger bid that is eventually successful in a given year. The dependent variable 'Local M\&As' is binary where 1 signifies that the firm acquired a local target within the successful M\&A deals. The dependent variable 'Target SOE' is binary where 1 signifies that the target firm is controlled by the state within the successful M\&A deals. 'CORRUPTION' is a dummy variable that is equal to one if a firm is a related firm, and zero otherwise. 'POST' is a dummy variable that is equal to one if the observation is obtained after the year of the corruption event, otherwise zero. 'CORP*POST' is the interaction between 'CORRUPTION' and 'POST'. Control variables are defined in Appendix B, and the standard errors are clustered by firm to account for any possible correlations between firms. The value reported is the marginal effect of independent variables; p-values in parentheses. *, **, *** represent significance at $10 \%, 5 \%$ and $1 \%$ levels, respectively.

\begin{tabular}{|c|c|c|c|c|c|c|}
\hline & \multicolumn{3}{|l|}{ FULL } & \multicolumn{3}{|c|}{ JURISDICTION } \\
\hline & M\&A & Local M\&A & Target SOEs & M\&A & Local M\&A & Target SOEs \\
\hline \multirow[t]{2}{*}{ CORRUPTION } & $0.080^{* * *}$ & $0.341^{* * *}$ & $0.204^{* * *}$ & $0.136 * * *$ & $0.317 * * *$ & $0.232 * * *$ \\
\hline & $(0.00)$ & $(0.00)$ & $(0.00)$ & $(0.00)$ & $(0.00)$ & $(0.01)$ \\
\hline \multirow[t]{2}{*}{ POST } & 0.007 & 0.101 & 0.052 & 0.006 & 0.055 & 0.081 \\
\hline & $(0.54)$ & $(0.14)$ & $(0.24)$ & $(0.71)$ & $(0.51)$ & $(0.11)$ \\
\hline \multirow[t]{2}{*}{ CORP*POST } & $-0.053 * * *$ & $-0.342 * * *$ & $-0.134 * *$ & $-0.052 * * *$ & $-0.325 * *$ & $-0.145 * *$ \\
\hline & $(0.00)$ & $(0.00)$ & $(0.01)$ & $(0.01)$ & $(0.02)$ & $(0.02)$ \\
\hline \multirow[t]{2}{*}{ SIZE } & $0.028 * * *$ & -0.034 & 0.021 & $0.029 * * *$ & -0.050 & $0.034 *$ \\
\hline & $(0.00)$ & $(0.34)$ & $(0.24)$ & $(0.00)$ & $(0.19)$ & $(0.09)$ \\
\hline \multirow[t]{2}{*}{$\mathrm{Q}$} & $0.017 * * *$ & -0.036 & 0.005 & $0.013 * * *$ & -0.024 & 0.009 \\
\hline & $(0.00)$ & $(0.12)$ & $(0.74)$ & $(0.01)$ & $(0.39)$ & $(0.58)$ \\
\hline \multirow[t]{2}{*}{ OPCFTA } & 0.051 & 0.42 & 0.261 & $0.104 *$ & 0.285 & 0.167 \\
\hline & $(0.28)$ & $(0.13)$ & $(0.18)$ & $(0.08)$ & $(0.33)$ & $(0.50)$ \\
\hline \multirow[t]{2}{*}{ LEVERAGE } & -0.004 & -0.041 & $0.068 *$ & -0.003 & $-0.143^{*}$ & $0.160 * * *$ \\
\hline & $(0.26)$ & $(0.60)$ & $(0.09)$ & $(0.37)$ & $(0.10)$ & $(0.01)$ \\
\hline \multirow[t]{2}{*}{ BOARDSIZE } & -0.005 & 0.014 & 0.014 & -0.005 & 0.020 & 0.018 \\
\hline & $(0.14)$ & $(0.40)$ & $(0.16)$ & $(0.17)$ & $(0.29)$ & $(0.17)$ \\
\hline \multirow[t]{2}{*}{ BOARDIND } & -0.015 & -0.525 & -0.061 & -0.050 & -0.372 & 0.227 \\
\hline & $(0.87)$ & $(0.34)$ & $(0.84)$ & $(0.65)$ & $(0.57)$ & $(0.60)$ \\
\hline OWNERSHIP & -0.070 & 0.379 & 0.183 & -0.051 & 0.298 & 0.318 \\
\hline
\end{tabular}




\begin{tabular}{lllllll} 
& $(0.25)$ & $(0.17)$ & $(0.30)$ & $(0.41)$ & $(0.34)$ & $(0.12)$ \\
INTERCEPT & $-10.915^{* * *}$ & 2.241 & $-9.288^{*}$ & $-12.292^{* * *}$ & $-9.353^{* *}$ & $-27.237^{* * *}$ \\
& $(0.00)$ & $(0.53)$ & $(0.08)$ & $(0.00)$ & $(0.02)$ & $(0.00)$ \\
\hline YEAR & YES & YES & YES & YES & YES & YES \\
INDUSTRY & YES & YES & YES & YES & YES & YES \\
N & 4875 & 376 & 380 & 3826 & 300 & 297 \\
pseudo R-sq & 0.08 & 0.10 & 0.17 & 0.09 & 0.11 & 0.19 \\
\hline
\end{tabular}


Table 4 Regression results for the impact of corruption events on M\&A premium

This table presents the regression results for the impact of corruption events on firms' takeover premium. 'FULL' includes all listed firms in the Shenzhen and Shanghai stock exchanges and 'JURISDICTION' only includes firms under corrupt bureaucrats' jurisdictions. The dependent variable 'PREMIUM1' is defined as the ratio of M\&A premium to estimated fair value of equity of target firm. The dependent variable 'PREMIUM2' is defined as the natural logarithm of the difference between the trading value and the estimated value of the target. 'CORRUPTION' is a dummy variable that is equal to one if a firm is a related firm, and zero otherwise. 'POST' is a dummy variable that is equal to one if the observation is obtained after the year of the corruption event, otherwise zero. 'CORP*POST' is the interaction between 'CORRUPTION' and 'POST'. Definition of control variables is in Appendix B, and the standard errors are clustered by firm to account for any possible correlations between firms. Standardized beta coefficients; p-values in parentheses. *, **, *** represent significance at $10 \%, 5 \%$ and $1 \%$ levels, respectively.

\begin{tabular}{|c|c|c|c|c|}
\hline & \multicolumn{2}{|c|}{ FULL } & \multicolumn{2}{|c|}{ JURISDICTION } \\
\hline & PREMIUM1 & PREMIUM2 & PREMIUM1 & PREMIUM2 \\
\hline \multirow[t]{2}{*}{ CORRUPTION } & -2.171 & $-0.027^{*}$ & -3.241 & -0.030 \\
\hline & $(0.14)$ & $(0.08)$ & $(0.13)$ & $(0.14)$ \\
\hline \multirow[t]{2}{*}{ POST } & 0.222 & -0.001 & -2.345 & -0.023 \\
\hline & $(0.85)$ & $(0.95)$ & $(0.20)$ & $(0.12)$ \\
\hline \multirow[t]{2}{*}{ CORP*POST } & $6.434^{* *}$ & $0.056^{* * *}$ & $7.444^{* *}$ & $0.064^{* *}$ \\
\hline & $(0.02)$ & $(0.01)$ & $(0.02)$ & $(0.01)$ \\
\hline \multirow[t]{2}{*}{ RELATIVE SIZE } & -0.088 & $0.016^{* * *}$ & -0.688 & $0.014 * * *$ \\
\hline & $(0.85)$ & $(0.00)$ & $(0.21)$ & $(0.00)$ \\
\hline \multirow[t]{2}{*}{ CASH PAYMENT } & -1.671 & -0.013 & -0.951 & -0.009 \\
\hline & $(0.22)$ & $(0.25)$ & $(0.57)$ & $(0.51)$ \\
\hline \multirow[t]{2}{*}{ SIZE } & $1.576^{*}$ & $0.018 * *$ & $2.176^{* * *}$ & $0.023 * * *$ \\
\hline & $(0.05)$ & $(0.04)$ & $(0.01)$ & $(0.01)$ \\
\hline \multirow[t]{2}{*}{ Q } & $1.625^{* *}$ & 0.004 & $2.911 * * *$ & 0.008 \\
\hline & $(0.03)$ & $(0.30)$ & $(0.01)$ & $(0.18)$ \\
\hline \multirow[t]{2}{*}{ OPCFTA } & 10.082 & $0.117 * *$ & 10.315 & $0.141^{* *}$ \\
\hline & $(0.10)$ & $(0.03)$ & $(0.11)$ & $(0.01)$ \\
\hline \multirow[t]{2}{*}{ LEVERAGE } & 0.760 & 0.014 & $3.034^{*}$ & 0.028 \\
\hline & $(0.60)$ & $(0.36)$ & $(0.08)$ & $(0.11)$ \\
\hline \multirow[t]{2}{*}{ BOARDSIZE } & -0.338 & -0.001 & -0.390 & -0.000 \\
\hline & $(0.29)$ & $(0.82)$ & $(0.26)$ & $(0.90)$ \\
\hline \multirow[t]{2}{*}{ BOARDIND } & $-23.683^{* *}$ & $-0.153^{* *}$ & $-17.435^{*}$ & $-0.151^{*}$ \\
\hline & $(0.01)$ & $(0.05)$ & $(0.05)$ & $(0.08)$ \\
\hline \multirow[t]{2}{*}{ OWNERSHIP } & $10.860^{* *}$ & 0.061 & $11.294^{* *}$ & 0.067 \\
\hline & $(0.05)$ & $(0.13)$ & $(0.04)$ & $(0.12)$ \\
\hline \multirow[t]{2}{*}{ INTERCEPT } & -19.975 & $22.671 * * *$ & $-42.419 * *$ & $22.550 * * *$ \\
\hline & $(0.22)$ & $(0.00)$ & $(0.04)$ & $(0.00)$ \\
\hline YEAR & YES & YES & YES & YES \\
\hline INDUSTRY & YES & YES & YES & YES \\
\hline $\mathrm{N}$ & 157 & 157 & 126 & 126 \\
\hline adj. R-sq & 0.28 & 0.43 & 0.32 & 0.39 \\
\hline
\end{tabular}


Table 5 Regression results for the impact of corruption events on firms' short-term post-M\&A performance.

This table presents the regression results for the impact of corruption events on firms' short-term post-M\&A performance. 'FULL' includes all listed firms in the Shenzhen and Shanghai stock exchanges and 'JURISDICTION' only includes firms under corrupt bureaucrats' jurisdictions. The dependent variable is post-M\&A performance measured by CARs for three-day, five-day and 11-day windows (CAR $(-1,1)$, CAR $(-2,2)$ and CAR (-5, 5)). 'CORRUPTION' is a dummy variable that is equal to one if a firm is a related firm, and zero otherwise. 'POST' is a dummy variable that is equal to one if the observation is obtained after the year of the corruption event, otherwise zero. 'CORP*POST' is the interaction between 'CORRUPTION' and 'POST'. Definition of control variables is in Appendix B, and the standard errors are clustered by firm to account for any possible correlations between firms. Standardized beta coefficients; p-values in parentheses. *,**,*** represent significance at $10 \%, 5 \%$ and $1 \%$ levels, respectively.

\begin{tabular}{|c|c|c|c|c|c|c|}
\hline & \multicolumn{3}{|c|}{ FULL } & \multicolumn{3}{|c|}{ JURISDICTION } \\
\hline & CAR $(-1,1)$ & CAR $(-2,2)$ & CAR $(-5,5)$ & CAR $(-1,1)$ & CAR $(-2,2)$ & CAR $(-5,5)$ \\
\hline \multirow[t]{2}{*}{ CORRUPTION } & $0.051^{*}$ & $0.050 * *$ & 0.002 & 0.012 & 0.013 & -0.000 \\
\hline & $(0.10)$ & $(0.03)$ & $(0.95)$ & $(0.33)$ & $(0.51)$ & $(0.99)$ \\
\hline \multirow[t]{2}{*}{ POST } & 0.016 & $0.030 * *$ & $0.047^{* *}$ & 0.016 & $0.034 *$ & $0.052^{* *}$ \\
\hline & $(0.19)$ & $(0.04)$ & $(0.02)$ & $(0.24)$ & $(0.09)$ & $(0.04)$ \\
\hline \multirow[t]{2}{*}{ CORP*POST } & $-0.119 * * *$ & $-0.133^{* * *}$ & $-0.093 * *$ & $-0.065^{* * *}$ & $-0.083 * * *$ & $-0.083 * *$ \\
\hline & $(0.01)$ & $(0.00)$ & $(0.03)$ & $(0.00)$ & $(0.00)$ & $(0.02)$ \\
\hline \multirow[t]{2}{*}{ RELATIVE SIZE } & $0.012^{* * *}$ & $0.016^{* * *}$ & $0.024 * * *$ & $0.014^{* * *}$ & $0.018^{* * *}$ & $0.025^{* * *}$ \\
\hline & $(0.00)$ & $(0.00)$ & $(0.00)$ & $(0.00)$ & $(0.00)$ & $(0.01)$ \\
\hline \multirow[t]{2}{*}{ CASH PAYMENT } & -0.033 & $-0.056^{* *}$ & $-0.075 * *$ & $-0.061^{* *}$ & $-0.076^{* *}$ & $-0.088 * *$ \\
\hline & $(0.12)$ & $(0.04)$ & $(0.02)$ & $(0.01)$ & $(0.02)$ & $(0.02)$ \\
\hline \multirow[t]{2}{*}{ SIZE } & 0.003 & $0.012 * *$ & $0.028 * * *$ & 0.004 & $0.014^{* *}$ & $0.024^{* *}$ \\
\hline & $(0.56)$ & $(0.04)$ & $(0.01)$ & $(0.30)$ & $(0.01)$ & $(0.01)$ \\
\hline \multirow[t]{2}{*}{ Q } & $0.008 *$ & $0.016^{* * *}$ & $0.029 * * *$ & $0.008^{*}$ & $0.018 * *$ & $0.024^{* *}$ \\
\hline & $(0.09)$ & $(0.01)$ & $(0.00)$ & $(0.07)$ & $(0.01)$ & $(0.04)$ \\
\hline \multirow{2}{*}{ OPCFTA } & 0.011 & 0.020 & -0.091 & -0.010 & -0.001 & -0.053 \\
\hline & $(0.79)$ & $(0.68)$ & $(0.16)$ & $(0.77)$ & $(0.99)$ & $(0.40)$ \\
\hline \multirow[t]{2}{*}{ LEVERAGE } & -0.012 & -0.023 & -0.034 & $-0.037 * * *$ & $-0.050 * * *$ & $-0.065^{*}$ \\
\hline & $(0.39)$ & $(0.16)$ & $(0.25)$ & $(0.00)$ & $(0.00)$ & $(0.07)$ \\
\hline \multirow[t]{2}{*}{ BOARDSIZE } & -0.006 & -0.004 & 0.004 & 0.000 & 0.001 & 0.004 \\
\hline & $(0.14)$ & $(0.37)$ & $(0.51)$ & $(0.98)$ & $(0.86)$ & $(0.43)$ \\
\hline BOARDIND & 0.051 & 0.044 & 0.085 & 0.120 & 0.085 & -0.090 \\
\hline
\end{tabular}




\begin{tabular}{lllllll} 
& $(0.52)$ & $(0.61)$ & $(0.51)$ & $(0.13)$ & $(0.48)$ & $(0.63)$ \\
OWNERSHIP & 0.061 & 0.061 & 0.023 & 0.050 & 0.062 & 0.045 \\
& $(0.17)$ & $(0.26)$ & $(0.69)$ & $(0.24)$ & $(0.28)$ & $(0.51)$ \\
INTERCEPT & 0.259 & -0.057 & $-0.742^{* * *}$ & -0.088 & $-0.331^{* *}$ & $-0.505^{* *}$ \\
& $(0.39)$ & $(0.79)$ & $(0.01)$ & $(0.40)$ & $(0.02)$ & $(0.03)$ \\
\hline YEAR & YES & YES & YES & YES & YES & YES \\
INDUSTRY & YES & YES & YES & YES & YES & 303 \\
N & 383 & 383 & 383 & 303 & 0.39 & 303 \\
adj. R-sq & 0.25 & 0.33 & 0.34 & 0.40 & 0.31 \\
\hline
\end{tabular}


Table 6 Regression results for the impact of corruption events on firms' long-term postM\&A performance.

This table presents the regression results for the impact of corruption events on firms' long-term postM\&A performance. 'FULL' includes all listed firms in the Shenzhen and Shanghai stock exchanges and 'JURISDICTION' only includes firms under corrupt bureaucrats' jurisdictions. The dependent variable is post-M\&A long-term market performance measured by buy and hold stock returns for oneyear, two-year and three-year windows (BHAR1, BHAR 2 and BHAR3). 'CORRUPTION' is a dummy variable that is equal to one if a firm is a related firm, and zero otherwise. 'POST' is a dummy variable that is equal to one if the observation is obtained after the year of the corruption event, otherwise zero. 'CORP*POST' is the interaction between 'CORRUPTION' and 'POST'. Definition of control variables is in Appendix B, and the standard errors are clustered by firm to account for any possible correlations between firms. Standardized beta coefficients; p-values in parentheses. *, **, *** represent significance at $10 \%, 5 \%$ and $1 \%$ levels, respectively.

\begin{tabular}{|c|c|c|c|c|c|c|}
\hline & \multicolumn{3}{|c|}{ FULL } & \multicolumn{3}{|c|}{ JURISDICTION } \\
\hline & BHAR1 & BHAR2 & BHAR3 & BHAR1 & BHAR2 & BHAR3 \\
\hline \multirow[t]{2}{*}{ CORRUPTION } & 0.161 & 0.355 & 0.443 & 0.226 & 0.363 & 0.505 \\
\hline & $(0.44)$ & $(0.19)$ & $(0.12)$ & $(0.42)$ & $(0.24)$ & $(0.17)$ \\
\hline \multirow[t]{2}{*}{ POST } & -0.004 & 0.130 & 0.111 & 0.026 & 0.184 & 0.174 \\
\hline & $(0.97)$ & $(0.33)$ & $(0.63)$ & $(0.85)$ & $(0.29)$ & $(0.57)$ \\
\hline \multirow[t]{2}{*}{ CORP*POST } & -0.290 & $-0.734 * *$ & $-1.210 * * *$ & -0.379 & $-0.690 *$ & $-1.234 * * *$ \\
\hline & $(0.19)$ & $(0.02)$ & $(0.00)$ & $(0.22)$ & $(0.08)$ & $(0.00)$ \\
\hline \multirow[t]{2}{*}{ RELATIVE SIZE } & 0.091 & $0.135^{* *}$ & 0.072 & $0.144^{* *}$ & $0.165^{* *}$ & 0.005 \\
\hline & $(0.18)$ & $(0.02)$ & $(0.20)$ & $(0.01)$ & $(0.01)$ & $(0.97)$ \\
\hline \multirow[t]{2}{*}{ CASH PAYMENT } & -0.171 & 0.066 & 0.087 & -0.175 & 0.004 & 0.124 \\
\hline & $(0.29)$ & $(0.78)$ & $(0.76)$ & $(0.39)$ & $(0.99)$ & $(0.75)$ \\
\hline \multirow[t]{2}{*}{ SIZE } & 0.073 & -0.029 & $-0.322 * *$ & $0.097^{* *}$ & -0.090 & $-0.488 * *$ \\
\hline & $(0.11)$ & $(0.68)$ & $(0.04)$ & $(0.01)$ & $(0.31)$ & $(0.02)$ \\
\hline \multirow[t]{2}{*}{$\mathrm{Q}$} & -0.015 & -0.089 & $-0.288 * *$ & 0.017 & -0.108 & -0.262 \\
\hline & $(0.65)$ & $(0.13)$ & $(0.01)$ & $(0.57)$ & $(0.23)$ & $(0.12)$ \\
\hline \multirow[t]{2}{*}{ OPCFTA } & -0.453 & -0.490 & -0.170 & $-0.833^{* *}$ & -0.749 & -0.446 \\
\hline & $(0.20)$ & $(0.30)$ & $(0.88)$ & $(0.02)$ & $(0.20)$ & $(0.76)$ \\
\hline \multirow[t]{2}{*}{ LEVERAGE } & -0.064 & -0.260 & 0.205 & -0.272 & $-0.568 * *$ & 0.461 \\
\hline & $(0.59)$ & $(0.16)$ & $(0.51)$ & $(0.10)$ & $(0.05)$ & $(0.56)$ \\
\hline \multirow[t]{2}{*}{ BOARDSIZE } & 0.039 & 0.006 & -0.003 & 0.029 & 0.036 & 0.036 \\
\hline & $(0.21)$ & $(0.92)$ & $(0.97)$ & $(0.38)$ & $(0.55)$ & $(0.69)$ \\
\hline \multirow[t]{2}{*}{ BOARDIND } & -0.400 & 0.083 & -1.094 & -0.434 & 0.921 & 0.469 \\
\hline & $(0.63)$ & $(0.95)$ & $(0.53)$ & $(0.63)$ & $(0.66)$ & $(0.87)$ \\
\hline \multirow[t]{2}{*}{ OWNERSHIP } & -0.374 & -1.103 & 1.130 & -0.523 & $-1.683^{*}$ & 0.069 \\
\hline & $(0.13)$ & $(0.11)$ & $(0.62)$ & $(0.13)$ & $(0.07)$ & $(0.97)$ \\
\hline \multirow[t]{2}{*}{ INTERCEPT } & -1.562 & 0.702 & $7.456^{* *}$ & -1.146 & 1.345 & $12.037 * * *$ \\
\hline & $(0.18)$ & $(0.65)$ & $(0.02)$ & $(0.33)$ & $(0.49)$ & $(0.01)$ \\
\hline YEAR & YES & YES & YES & YES & YES & YES \\
\hline INDUSTRY & YES & YES & YES & YES & YES & YES \\
\hline $\mathrm{N}$ & 368 & 266 & 189 & 294 & 206 & 142 \\
\hline adj. R-sq & 0.11 & 0.08 & 0.03 & 0.14 & 0.18 & 0.05 \\
\hline
\end{tabular}


Table 7 Anti-corruption events and M\&A decisions: excluding the effect from bribing firms

\section{Panel A M\&A decisions}

This table presents logistic regression results for the impact of corruption events on M\&A decisions. Bribing firms are excluded in all regression models. The dependent variable 'M\&A' is binary where 1 signifies that the firm makes at least one merger bid that is eventually successful in a given year. The dependent variable 'Local M\&As' is binary where 1 signifies that the firm acquired a local target within the successful M\&A deals. The dependent variable 'Target SOE' is binary where 1 signifies that the target firm is controlled by the state within the successful M\&A deals. 'CORRUPTION' is a dummy variable that is equal to one if a firm is connected with the corrupt bureaucrat through past job affiliations and educational experience but never bribed the corrupt bureaucrat, and zero otherwise. 'POST' is a dummy variable that is equal to one if the observation is obtained after the year of the corruption event, otherwise zero. 'CORP*POST' is the interaction between 'CORRUPTION' and 'POST'. The standard errors are clustered by firm to account for any possible correlations between firms. The value reported is the marginal effect of independent variables; p-values in parentheses. *, $* *, * * *$ represent significance at $10 \%, 5 \%$ and $1 \%$ levels, respectively.

\begin{tabular}{llll}
\hline & M\&A & Local M\&A & SOE Target \\
\hline CORRUPTION & $0.139^{* * *}$ & $0.357^{* * *}$ & $0.224^{* * *}$ \\
POST & $(0.00)$ & $(0.00)$ & $(0.00)$ \\
& 0.009 & 0.112 & 0.063 \\
CORP*POST & $(0.48)$ & $(0.10)$ & $(0.18)$ \\
& $-0.059^{* * *}$ & $-0.369^{* * *}$ & $-0.133^{* *}$ \\
SIZE & $(0.00)$ & $(0.00)$ & $(0.02)$ \\
& $0.031^{* * *}$ & -0.047 & 0.018 \\
Q & $(0.00)$ & $(0.23)$ & $(0.32)$ \\
OPCFTA & $0.017^{* * *}$ & -0.037 & 0.006 \\
& $(0.00)$ & $(0.13)$ & $(0.65)$ \\
LEVERAGE & 0.064 & 0.419 & 0.257 \\
BOARDSIZE & $(0.21)$ & $(0.13)$ & $(0.19)$ \\
BOARDIND & -0.005 & 0.005 & $0.078^{*}$ \\
OWNERSHIP & $(0.20)$ & $(0.95)$ & $(0.07)$ \\
INTERCEPT & -0.005 & 0.015 & 0.014 \\
& $(0.18)$ & $(0.40)$ & $(0.15)$ \\
YEAR & 0.002 & -0.525 & -0.099 \\
INDUSTRY & $(0.98)$ & $(0.34)$ & $(0.75)$ \\
N & -0.065 & 0.368 & 0.180 \\
pseudo R-sq & $(0.27)$ & $(0.19)$ & $(0.31)$ \\
\hline & $-12.047^{* * *}$ & 3.285 & -7.081 \\
& $(0.00)$ & $(0.39)$ & $(0.16)$ \\
\hline & YES & YES & YES \\
YES & YES & 365 \\
& 4564 & 367 & 0.17 \\
\hline
\end{tabular}




\section{Panel B Takeover premium}

This table presents the regression results for the impact of corruption events on firms' takeover premium. Bribing firms are excluded in all regression models. The dependent variable 'PREMIUM1' is defined as the ratio of M\&A premium to estimated fair value of equity of target firm. The dependent variable 'PREMIUM2' is defined as the natural logarithm of the difference between the trading value and the estimated value of the target. 'CORRUPTION' is a dummy variable that is equal to one if a firm is connected with the corrupt bureaucrat through past job affiliations and educational experience but never bribed the corrupt bureaucrat, and zero otherwise. 'POST' is a dummy variable that is equal to one if the observation is obtained after the year of the corruption event, otherwise zero. 'CORP*POST' is the interaction between 'CORRUPTION' and 'POST'. The standard errors are clustered by firm to account for any possible correlations between firms. Standardized beta coefficients; p-values in parentheses. *, **, *** represent significance at $10 \%, 5 \%$ and $1 \%$ levels, respectively.

\begin{tabular}{|c|c|c|}
\hline & PREMIUM1 & PREMIUM2 \\
\hline \multirow[t]{2}{*}{ CORRUPTION } & -2.532 & $-0.025^{*}$ \\
\hline & $(0.10)$ & $(0.10)$ \\
\hline \multirow[t]{2}{*}{ POST } & -0.051 & 0.000 \\
\hline & $(0.97)$ & $(0.99)$ \\
\hline \multirow[t]{2}{*}{ CORP*POST } & $6.634^{* *}$ & $0.059 * * *$ \\
\hline & $(0.02)$ & $(0.01)$ \\
\hline \multirow[t]{2}{*}{ RELATIVE SIZE } & -0.177 & $0.017 * * *$ \\
\hline & $(0.72)$ & $(0.00)$ \\
\hline \multirow[t]{2}{*}{ CASH PAYMENT } & -1.550 & -0.012 \\
\hline & $(0.25)$ & $(0.26)$ \\
\hline \multirow[t]{2}{*}{ SIZE } & $1.959 * *$ & $0.016^{*}$ \\
\hline & $(0.03)$ & $(0.10)$ \\
\hline \multirow[t]{2}{*}{$\mathrm{Q}$} & $1.897 * *$ & 0.003 \\
\hline & $(0.03)$ & $(0.60)$ \\
\hline \multirow[t]{2}{*}{ OPCFTA } & 9.007 & $0.124 * *$ \\
\hline & $(0.13)$ & $(0.02)$ \\
\hline \multirow[t]{2}{*}{ LEVERAGE } & -1.451 & $0.023^{*}$ \\
\hline & $(0.39)$ & $(0.08)$ \\
\hline \multirow[t]{2}{*}{ BOARDSIZE } & -0.414 & -0.000 \\
\hline & $(0.20)$ & $(0.95)$ \\
\hline \multirow[t]{2}{*}{ BOARDIND } & $-22.782 * *$ & $-0.146 *$ \\
\hline & $(0.02)$ & $(0.06)$ \\
\hline \multirow[t]{2}{*}{ OWNERSHIP } & $10.279 *$ & 0.061 \\
\hline & $(0.05)$ & $(0.14)$ \\
\hline \multirow[t]{2}{*}{ INTERCEPT } & -27.481 & $22.768 * * *$ \\
\hline & $(0.12)$ & $(0.00)$ \\
\hline YEAR & YES & YES \\
\hline INDUSTRY & YES & YES \\
\hline $\mathrm{N}$ & 154 & 154 \\
\hline adj. R-sq & 0.29 & 0.52 \\
\hline
\end{tabular}


Panel C Short-term post-M\&A performance

This table presents the regression results for the impact of anti-corruption events on the short-term postM\&A performance of related firms. Bribing firms are excluded in all regression models. The dependent variable is post-M\&A performance measured by CARs for three-day, five-day and 11-day windows (CAR $(-1,1)$, CAR $(-2,2)$ and CAR $(-5,5))$. 'CORRUPTION' is a dummy variable that is equal to one if a firm is connected with the corrupt bureaucrat through past job affiliations and educational experience but never bribed the corrupt bureaucrat, and zero otherwise. 'POST' is a dummy variable that is equal to one if the observation is obtained after the year of the corruption event, otherwise zero. 'CORP*POST' is the interaction between 'CORRUPTION' and 'POST'. The standard errors are clustered by firm to account for any possible correlations between firms. Standardized beta coefficients. P-values in parentheses. *, **, *** represent significance at $10 \%, 5 \%$ and $1 \%$ levels, respectively.

\begin{tabular}{|c|c|c|c|}
\hline & $\operatorname{CAR}(-1,1)$ & CAR $(-2,2)$ & CAR $(-5,5)$ \\
\hline \multirow[t]{2}{*}{ CORRUPTION } & $0.056 *$ & $0.051 * *$ & 0.004 \\
\hline & $(0.09)$ & $(0.03)$ & $(0.88)$ \\
\hline \multirow[t]{2}{*}{ POST } & 0.019 & $0.033 * *$ & $0.049 * *$ \\
\hline & $(0.13)$ & $(0.03)$ & $(0.01)$ \\
\hline \multirow[t]{2}{*}{ CORP*POST } & $-0.129 * *$ & $-0.135 * * *$ & $-0.084^{*}$ \\
\hline & $(0.01)$ & $(0.00)$ & $(0.08)$ \\
\hline \multirow[t]{2}{*}{ RELATIVE SIZE } & $0.014^{* * *}$ & $0.019 * * *$ & $0.031^{* * *}$ \\
\hline & $(0.00)$ & $(0.00)$ & $(0.00)$ \\
\hline \multirow[t]{2}{*}{ CASH PAYMENT } & -0.028 & $-0.052 *$ & $-0.056^{*}$ \\
\hline & $(0.22)$ & $(0.07)$ & $(0.07)$ \\
\hline \multirow[t]{2}{*}{ SIZE } & -0.002 & 0.005 & 0.013 \\
\hline & $(0.74)$ & $(0.47)$ & $(0.16)$ \\
\hline \multirow[t]{2}{*}{ Q } & 0.007 & $0.013 * *$ & $0.022 * * *$ \\
\hline & $(0.15)$ & $(0.03)$ & $(0.01)$ \\
\hline \multirow[t]{2}{*}{ OPCFTA } & 0.019 & 0.035 & -0.067 \\
\hline & $(0.64)$ & $(0.49)$ & $(0.27)$ \\
\hline \multirow[t]{2}{*}{ LEVERAGE } & 0.002 & 0.003 & 0.020 \\
\hline & $(0.90)$ & $(0.85)$ & $(0.34)$ \\
\hline \multirow[t]{2}{*}{ BOARDSIZE } & -0.006 & -0.004 & 0.003 \\
\hline & $(0.14)$ & $(0.36)$ & $(0.60)$ \\
\hline \multirow[t]{2}{*}{ BOARDIND } & 0.056 & 0.061 & 0.133 \\
\hline & $(0.49)$ & $(0.48)$ & $(0.29)$ \\
\hline \multirow[t]{2}{*}{ OWNERSHIP } & 0.055 & 0.054 & 0.008 \\
\hline & $(0.22)$ & $(0.32)$ & $(0.88)$ \\
\hline \multirow[t]{2}{*}{ INTERCEPT } & 0.349 & 0.087 & $-0.473 *$ \\
\hline & $(0.27)$ & $(0.70)$ & $(0.08)$ \\
\hline YEAR & YES & YES & YES \\
\hline INDUSTRY & YES & YES & YES \\
\hline $\mathrm{N}$ & 374 & 374 & 374 \\
\hline adj. R-sq & 0.25 & 0.35 & 0.37 \\
\hline
\end{tabular}




\section{Panel D Long-term post-M\&A performance}

This table presents the regression results for the impact of anti-corruption events on the long-term postM\&A performance of related firms. Bribing firms are excluded in all regression models. The dependent variable is post-M\&A long-term market performance measured by buy and hold stock return for oneyear, two-year and three-year windows (BHAR1, BHAR 2 and BHAR3). 'CORRUPTION' is a dummy variable that is equal to one if a firm is connected with the corrupt bureaucrat through past job affiliations and educational experience but never bribed the corrupt bureaucrat, and zero otherwise. 'POST' is a dummy variable that is equal to one if the observation is obtained after the year of the corruption event, otherwise zero. 'CORP*POST' is the interaction between 'CORRUPTION' and 'POST'. The standard errors are clustered by firm to account for any possible correlations between firms. Standardized beta coefficients. P-values in parentheses. *, **, *** represent significance at $10 \%$, $5 \%$ and $1 \%$ levels, respectively.

\begin{tabular}{|c|c|c|c|}
\hline & BHAR1 & BHAR2 & BHAR3 \\
\hline \multirow[t]{2}{*}{ CORRUPTION } & 0.117 & 0.373 & 0.416 \\
\hline & $(0.59)$ & $(0.20)$ & $(0.15)$ \\
\hline \multirow[t]{2}{*}{ POST } & 0.013 & 0.181 & 0.139 \\
\hline & $(0.89)$ & $(0.22)$ & $(0.55)$ \\
\hline \multirow[t]{2}{*}{ CORP*POST } & -0.228 & $-0.627^{*}$ & $-1.171^{* * *}$ \\
\hline & $(0.35)$ & $(0.08)$ & $(0.00)$ \\
\hline \multirow[t]{2}{*}{ RELATIVE SIZE } & 0.109 & $0.162 * * *$ & 0.060 \\
\hline & $(0.13)$ & $(0.00)$ & $(0.29)$ \\
\hline \multirow[t]{2}{*}{ CASH PAYMENT } & -0.144 & 0.102 & 0.035 \\
\hline & $(0.41)$ & $(0.68)$ & $(0.90)$ \\
\hline \multirow[t]{2}{*}{ SIZE } & 0.028 & -0.146 & $-0.322 * *$ \\
\hline & $(0.51)$ & $(0.12)$ & $(0.04)$ \\
\hline \multirow[t]{2}{*}{$\mathrm{Q}$} & -0.031 & $-0.131^{* *}$ & $-0.268 * *$ \\
\hline & $(0.38)$ & $(0.04)$ & $(0.02)$ \\
\hline \multirow[t]{2}{*}{ OPCFTA } & -0.349 & -0.297 & -0.163 \\
\hline & $(0.34)$ & $(0.54)$ & $(0.89)$ \\
\hline \multirow[t]{2}{*}{ LEVERAGE } & 0.100 & 0.036 & 0.239 \\
\hline & $(0.19)$ & $(0.75)$ & $(0.45)$ \\
\hline \multirow[t]{2}{*}{ BOARDSIZE } & 0.041 & 0.011 & 0.007 \\
\hline & $(0.17)$ & $(0.83)$ & $(0.92)$ \\
\hline \multirow[t]{2}{*}{ BOARDIND } & -0.196 & 0.350 & -1.005 \\
\hline & $(0.81)$ & $(0.81)$ & $(0.56)$ \\
\hline \multirow[t]{2}{*}{ OWNERSHIP } & -0.405 & $-1.170^{*}$ & 1.279 \\
\hline & $(0.11)$ & $(0.09)$ & $(0.58)$ \\
\hline \multirow[t]{2}{*}{ INTERCEPT } & -0.804 & $4.100^{*}$ & $7.416^{* *}$ \\
\hline & $(0.47)$ & $(0.06)$ & $(0.02)$ \\
\hline YEAR & YES & YES & YES \\
\hline INDUSTRY & YES & YES & YES \\
\hline $\mathrm{N}$ & 359 & 260 & 187 \\
\hline adj. R-sq & 0.11 & 0.12 & 0.03 \\
\hline
\end{tabular}


Table 8 Regression results for the impact of corruption events on M\&A decisions before the corruption event

\section{Panel A M\&A decisions}

This table presents logistic regression results for the impact of corruption events on firms' M\&A decisions before the corruption events. The dependent variable ' $M \& A$ ' is binary where 1 signifies that the firm makes at least one merger bid that is eventually successful in a given year. The dependent variable 'LOCAL' is binary where 1 signifies that the firm acquired a local target within successful M\&A deals. The dependent variable 'Target SOE' is binary where 1 signifies that the target firm is controlled by the state within the successful M\&A deals. 'CORRUPTION' is a dummy variable that is equal to one if a firm is a related firm, and zero otherwise. The standard errors are clustered by firm to account for any possible correlations between firms. The value reported is the marginal effect of independent variables; p-values in parentheses. *, **, *** represent significance at $10 \%, 5 \%$ and $1 \%$ levels, respectively.

\begin{tabular}{llll}
\hline & M\&A & Local M\&A & SOE Target \\
\hline CORRUPTION & $0.086^{* * *}$ & $0.298^{* * *}$ & $0.299^{* * *}$ \\
SIZE & $(0.00)$ & $(0.00)$ & $(0.00)$ \\
Q & $0.032^{* * *}$ & 0.042 & -0.016 \\
& $(0.00)$ & $(0.36)$ & $(0.66)$ \\
OPCFTA & $0.028^{* * *}$ & -0.029 & 0.050 \\
& $(0.00)$ & $(0.44)$ & $(0.17)$ \\
LEVERAGE & -0.042 & $1.000^{* * *}$ & $0.890^{* *}$ \\
& $(0.52)$ & $(0.00)$ & $(0.03)$ \\
BOARDSIZE & -0.012 & 0.126 & -0.007 \\
& $(0.29)$ & $(0.14)$ & $(0.93)$ \\
BOARDIND & -0.008 & 0.001 & 0.009 \\
& $(0.11)$ & $(0.95)$ & $(0.70)$ \\
OWNERSHIP & -0.062 & -0.993 & -0.675 \\
& $(0.66)$ & $(0.16)$ & $(0.30)$ \\
INTERCEPT & 0.036 & -0.012 & -0.012 \\
& $(0.78)$ & $(0.98)$ & $(0.99)$ \\
\hline YEAR & $-12.515^{* * *}$ & -4.596 & 2.664 \\
INDUSTRY & $(0.00)$ & $(0.39)$ & $(0.70)$ \\
N & YES & YES & YES \\
pseudo R-sq & YES & YES & YES \\
\hline
\end{tabular}




\section{Panel B Takeover premium}

This table presents the regression results for the impact of corruption events on firms' takeover premium before the corruption events. The dependent variable 'PREMIUM1' is defined as the ratio of total takeover premium to the fair value of equity of the target firm. 'PREMIUM2' is defined as the log of the total takeover premium measured by the difference between the sum of trading value of the target and the estimated fair value. 'CORRUPTION' is a dummy variable that is equal to one if a firm is a related firm, and zero otherwise. The standard errors are clustered by firm to account for any possible correlations between firms. Standardized beta coefficients; $\mathrm{p}$-values in parentheses. *, **, *** represent significance at $10 \%, 5 \%$ and $1 \%$ levels, respectively.

\begin{tabular}{lll}
\hline & PREMIUM1 & PREMIUM2 \\
\hline CORRUPTION & $-3.137^{*}$ & $-0.023^{* *}$ \\
RELATIVE SIZE & $(0.05)$ & $(0.05)$ \\
CASH PAYMENT & 0.774 & $0.020^{* *}$ \\
& $(0.16)$ & $(0.04)$ \\
SIZE & -0.454 & 0.016 \\
& $(0.85)$ & $(0.50)$ \\
Q & 0.573 & -0.017 \\
& $(0.49)$ & $(0.43)$ \\
OPCFTA & 0.049 & -0.012 \\
& $(0.96)$ & $(0.47)$ \\
LEVERAGE & -3.130 & 0.189 \\
BOARDSIZE & $(0.77)$ & $(0.41)$ \\
BOARDIND & -0.212 & 0.017 \\
OWNERSHIP & $(0.93)$ & $(0.48)$ \\
INTERCEPT & -0.129 & 0.002 \\
YEAR & $(0.81)$ & $(0.83)$ \\
INDUSTRY & -6.363 & -0.171 \\
adj. R-sq & $(0.76)$ & $(0.71)$ \\
\hline & $22.078^{* *}$ & 0.098 \\
& $(0.01)$ & $(0.45)$ \\
\hline & -6.957 & $23.408^{* * *}$ \\
& $(0.74)$ & $(0.00)$ \\
\hline & YES & YES \\
YES & 60 \\
& 60 & 0.42 \\
\hline
\end{tabular}


Panel C Short-term post-M\&A performance

This table presents the regression results for the impact of corruption events on firms' short-term postM\&A performance before the corruption events. The dependent variable is post-M\&A performance measured by CARs for three-day, five-day and 11-day windows (CAR $(-1,1)$, CAR $(-2,2)$ and CAR ($5,5)$ ). 'CORRUPTION' is a dummy variable that is equal to one if a firm is a related firm, and zero otherwise. The standard errors are clustered by firm to account for any possible correlations between firms. Standardized beta coefficients; p-values in parentheses. *, **, *** represent significance at $10 \%$, $5 \%$ and $1 \%$ levels, respectively.

\begin{tabular}{llll}
\hline & CAR $(-1,1)$ & CAR $(-2,2)$ & CAR $(-5,5)$ \\
\hline CORRUPTION & 0.051 & $0.045^{*}$ & -0.004 \\
RELATIVE SIZE & $(0.12)$ & $(0.06)$ & $(0.89)$ \\
CASH PAYMENT & $0.012^{*}$ & $0.015^{* *}$ & $0.024^{* * *}$ \\
SIZE & $(0.09)$ & $(0.03)$ & $(0.00)$ \\
& -0.005 & -0.030 & -0.053 \\
Q & $(0.87)$ & $(0.38)$ & $(0.16)$ \\
& -0.005 & 0.014 & $0.035^{* *}$ \\
OPCFTA & $(0.74)$ & $(0.32)$ & $(0.04)$ \\
& 0.011 & $0.024^{* *}$ & $0.039^{* * *}$ \\
LEVERAGE & $(0.22)$ & $(0.02)$ & $(0.00)$ \\
BOARDSIZE & 0.058 & 0.076 & -0.088 \\
BOARDIND & $(0.39)$ & $(0.42)$ & $(0.39)$ \\
& -0.001 & 0.002 & 0.032 \\
OWNERSHIP & $(0.96)$ & $(0.92)$ & $(0.23)$ \\
INTERCEPT & -0.010 & -0.008 & 0.005 \\
& $(0.14)$ & $(0.24)$ & $(0.55)$ \\
YEAR & -0.061 & -0.020 & 0.231 \\
INDUSTRY & $(0.65)$ & $(0.88)$ & $(0.19)$ \\
N & $0.151^{*}$ & 0.114 & -0.007 \\
adj. R-sq & $(0.08)$ & $(0.31)$ & $(0.95)$ \\
\hline & 0.610 & 0.030 & $-1.076^{* *}$ \\
& $(0.32)$ & $(0.94)$ & $(0.03)$ \\
\hline & YES & YES & YES \\
YES & YES & 171 \\
& 171 & 171 & 0.33 \\
\hline
\end{tabular}




\section{Panel D Long-term post-M\&A performance}

This table presents the regression results for the impact of corruption events on firms' long-term postM\&A performance before the corruption events. The dependent variable is post-M\&A long-term market performance measured by buy and hold stock returns for one-year, two-year and three-year windows (BHAR1, BHAR2 and BHAR3). 'CORRUPTION' is a dummy variable that is equal to one if a firm is a related firm, and zero otherwise. The standard errors are clustered by firm to account for any possible correlations between firms. Standardized beta coefficients; p-values in parentheses. *, **, *** represent significance at $10 \%, 5 \%$ and $1 \%$ levels, respectively.

\begin{tabular}{llll}
\hline & BHAR1 & BHAR2 & BHAR3 \\
\hline CORRUPTION & 0.144 & $0.391^{*}$ & $0.572^{* *}$ \\
RELATIVE SIZE & $(0.52)$ & $(0.08)$ & $(0.04)$ \\
& -0.061 & 0.003 & -0.024 \\
CASH PAYMENT & $(0.15)$ & $(0.97)$ & $(0.73)$ \\
& -0.335 & -0.040 & 0.155 \\
SIZE & $(0.21)$ & $(0.90)$ & $(0.69)$ \\
& 0.057 & -0.090 & -0.234 \\
Q & $(0.61)$ & $(0.48)$ & $(0.14)$ \\
OPCFTA & 0.065 & 0.015 & -0.095 \\
& $(0.44)$ & $(0.90)$ & $(0.46)$ \\
LEVERAGE & -0.923 & -1.043 & -0.951 \\
BOARDSIZE & $(0.15)$ & $(0.29)$ & $(0.42)$ \\
BOARDIND & 0.031 & -0.142 & -0.091 \\
& $(0.81)$ & $(0.59)$ & $(0.83)$ \\
OWNERSHIP & 0.045 & 0.003 & -0.032 \\
INTERCEPT & $(0.28)$ & $(0.96)$ & $(0.64)$ \\
& -0.756 & 1.360 & -1.850 \\
YEAR & $(0.60)$ & $(0.49)$ & $(0.37)$ \\
INDUSTRY & -0.303 & -0.981 & 4.962 \\
N & $(0.68)$ & $(0.46)$ & $(0.14)$ \\
adj. R-sq & -1.065 & 2.759 & $6.105 *$ \\
\hline
\end{tabular}


Table 9 Regression results for the impact of corruption events on short-term post-M\&A performance for firms with longer-term connections with corrupt bureaucrats.

The table presents the regression results for the impact of corruption events on short-term post-M\&A performance for firms which have longer-term connections with corrupt bureaucrats. In columns 1 to 3 , the sample only includes the deals announced by firms that establish connections with corrupt bureaucrats one year before the announcement of M\&As. In columns 4 to 6 and 7 to 9 , the sample only includes the deals announced by firms that establish connections with corrupt bureaucrats two and three years before the announcement of M\&As, respectively. The dependent variable is post-M\&A performance measured by CARs for three-day, five-day and 11-day windows (CAR $(-1,1)$, CAR $(-2,2)$ and CAR $(-5,5))$. 'CORRUPTION' is a dummy variable that equals one if a firm is a related firm, and zero otherwise. 'POST' is a dummy variable that is equal to one if the observation is obtained after the year of the corruption event, otherwise zero. 'CORP*POST' is the interaction between 'CORRUPTION' and 'POST'. Definition of control variables is in Appendix B and the standard errors are clustered by firm to account for any possible correlations between firms. Standardized beta coefficients; p-values in parentheses. *, **, *** represent significance at $10 \%$, $5 \%$ and $1 \%$ levels, respectively.

\begin{tabular}{|c|c|c|c|c|c|c|c|c|c|}
\hline & \multicolumn{3}{|c|}{ Connection established one year before } & \multicolumn{3}{|c|}{ Connection established two years before } & \multicolumn{3}{|c|}{ Connection established three years before } \\
\hline & $\operatorname{CAR}(-1,1)$ & $\operatorname{CAR}(-2,2)$ & $\operatorname{CAR}(-5,5)$ & $\operatorname{CAR}(-1,1)$ & CAR $(-2,2)$ & $\operatorname{CAR}(-5,5)$ & $\operatorname{CAR}(-1,1)$ & $\operatorname{CAR}(-2,2)$ & CAR $(-5,5)$ \\
\hline \multirow[t]{2}{*}{ CORRUPTION } & 0.053 & $0.052 * *$ & -0.010 & 0.055 & $0.053^{* *}$ & -0.012 & 0.056 & $0.049 * *$ & -0.019 \\
\hline & $(0.11)$ & $(0.03)$ & $(0.72)$ & $(0.11)$ & $(0.03)$ & $(0.68)$ & $(0.12)$ & $(0.04)$ & $(0.52)$ \\
\hline \multirow[t]{2}{*}{ POST } & 0.015 & $0.029 * *$ & $0.048 * *$ & 0.015 & $0.029 * *$ & $0.048 * *$ & 0.015 & $0.030 * *$ & $0.048 * *$ \\
\hline & $(0.20)$ & $(0.04)$ & $(0.01)$ & $(0.21)$ & $(0.04)$ & $(0.01)$ & $(0.21)$ & $(0.04)$ & $(0.01)$ \\
\hline \multirow[t]{2}{*}{ CORP*POST } & $-0.119 * *$ & $-0.135 * * *$ & $-0.082 *$ & $-0.126 * *$ & $-0.144 * * *$ & $-0.088 *$ & $-0.128 * *$ & $-0.141 * * *$ & $-0.082 *$ \\
\hline & $(0.01)$ & $(0.00)$ & $(0.07)$ & $(0.01)$ & $(0.00)$ & $(0.06)$ & $(0.01)$ & $(0.00)$ & $(0.08)$ \\
\hline \multirow[t]{2}{*}{ RELATIVE SIZE } & $0.012^{* * *}$ & $0.016 * * *$ & $0.023 * * *$ & $0.012^{* * *}$ & $0.016 * * *$ & $0.023 * * *$ & $0.012 * * *$ & $0.017 * * *$ & $0.024 * * *$ \\
\hline & $(0.00)$ & $(0.00)$ & $(0.00)$ & $(0.00)$ & $(0.00)$ & $(0.00)$ & $(0.00)$ & $(0.00)$ & $(0.00)$ \\
\hline \multirow[t]{2}{*}{ CASH PAYMENT } & $-0.037^{*}$ & $-0.059 * *$ & $-0.076 * *$ & $-0.037^{*}$ & $-0.060 * *$ & $-0.078 * *$ & $-0.037 *$ & $-0.059 * *$ & $-0.077 * *$ \\
\hline & $(0.09)$ & $(0.03)$ & $(0.02)$ & $(0.09)$ & $(0.03)$ & $(0.01)$ & $(0.09)$ & $(0.03)$ & $(0.01)$ \\
\hline \multirow[t]{2}{*}{ SIZE } & 0.002 & $0.012^{* *}$ & $0.030 * * *$ & 0.003 & $0.013 * *$ & $0.031^{* * *}$ & 0.002 & $0.014^{* *}$ & $0.032 * * *$ \\
\hline & $(0.64)$ & $(0.04)$ & $(0.00)$ & $(0.59)$ & $(0.03)$ & $(0.00)$ & $(0.63)$ & $(0.01)$ & $(0.00)$ \\
\hline \multirow[t]{2}{*}{ Q } & 0.008 & $0.016^{* * *}$ & $0.031^{* * *}$ & $0.008^{*}$ & $0.017 * * *$ & $0.032 * * *$ & 0.008 & $0.017 * * *$ & $0.032^{* * *}$ \\
\hline & $(0.11)$ & $(0.01)$ & $(0.00)$ & $(0.10)$ & $(0.01)$ & $(0.00)$ & $(0.10)$ & $(0.01)$ & $(0.00)$ \\
\hline \multirow[t]{2}{*}{ OPCFTA } & 0.024 & 0.025 & -0.106 & 0.024 & 0.025 & -0.104 & 0.025 & 0.011 & $-0.117 *$ \\
\hline & $(0.56)$ & $(0.62)$ & $(0.11)$ & $(0.55)$ & $(0.62)$ & $(0.12)$ & $(0.54)$ & $(0.82)$ & $(0.08)$ \\
\hline \multirow[t]{2}{*}{ LEVERAGE } & -0.013 & -0.023 & -0.033 & -0.012 & -0.022 & -0.032 & -0.012 & -0.021 & -0.032 \\
\hline & $(0.36)$ & $(0.16)$ & $(0.27)$ & (0.39) & $(0.18)$ & $(0.28)$ & $(0.39)$ & $(0.18)$ & $(0.27)$ \\
\hline
\end{tabular}




\begin{tabular}{llllllllll} 
BOARDSIZE & -0.006 & -0.003 & 0.004 & -0.006 & -0.004 & 0.003 & -0.006 & -0.005 & 0.002 \\
& $(0.16)$ & $(0.39)$ & $(0.47)$ & $(0.16)$ & $(0.35)$ & $(0.55)$ & $(0.16)$ & $(0.22)$ & $(0.73)$ \\
BOARDIND & 0.044 & 0.048 & 0.115 & 0.042 & 0.045 & 0.109 & 0.039 & 0.044 & 0.103 \\
& $(0.60)$ & $(0.59)$ & $(0.38)$ & $(0.62)$ & $(0.61)$ & $(0.40)$ & $(0.64)$ & $(0.62)$ & $(0.43)$ \\
OWNERSHIP & 0.061 & 0.062 & 0.030 & 0.047 & 0.049 & 0.015 & 0.045 & 0.057 & 0.024 \\
& $(0.17)$ & $(0.25)$ & $(0.62)$ & $(0.32)$ & $(0.38)$ & $(0.78)$ & $(0.34)$ & $(0.30)$ & $(0.66)$ \\
INTERCEPT & 0.318 & -0.019 & $-0.777^{* * *}$ & 0.312 & -0.028 & $-0.781^{* * *}$ & 0.316 & -0.049 & $-0.798^{* * *}$ \\
& $(0.31)$ & $(0.93)$ & $(0.00)$ & $(0.31)$ & $(0.89)$ & $(0.00)$ & $(0.31)$ & $(0.82)$ & $(0.00)$ \\
\hline YEAR & YES & YES & YES & YES & YES & YES & YES & YES & YES \\
INDUSTRY & YES & YES & YES & YES & YES & YES & YES & YES & YES \\
N & 377 & 377 & 377 & 373 & 373 & 373 & 370 & 370 & 370 \\
adj. R-sq & 0.25 & 0.33 & 0.34 & 0.25 & 0.34 & 0.35 & 0.25 & 0.35 \\
\hline
\end{tabular}


Table 10 Regression results for the impact of corruption events on firms' post-M\&A performance stratified by different firm performance.

This table presents the regression results for the impact of corruption events on firms' post-M\&A performance in the subsamples alternately stratified by firm performance. The sample is partitioned alternately by the sample median value of firm return on equity (ROE) and Tobin's Q. The 'Low' and 'High' subsamples refer to the firm having ROE or Tobin's Q lower and higher than the sample median value, respectively. The dependent variable is post-M\&A performance measured by CARs for threeday, five-day and 11-day windows (CAR $(-1,1)$, CAR $(-2,2)$ and CAR $(-5,5))$. 'CORRUPTION' is a dummy variable that equals one if a firm is a related firm, and zero otherwise. 'POST' is a dummy variable that is equal to one if the observation is obtained after the year of the corruption event, otherwise zero. 'CORP*POST' is the interaction between 'CORRUPTION' and 'POST'. Definition of control variables is in Appendix B, and the standard errors are clustered by firm to account for any possible correlations between firms. Standardized beta coefficients; p-values in parentheses. *, **, *** represent significance at $10 \%, 5 \%$ and $1 \%$ levels, respectively.

Panel A Firm performance: Firm return on equity (ROE)

\begin{tabular}{|c|c|c|c|c|c|c|}
\hline & $\begin{array}{l}\text { Low } \\
\text { CAR } \\
(-1,1) \\
\end{array}$ & $\begin{array}{l}\text { High } \\
\text { CAR } \\
(-1,1) \\
\end{array}$ & $\begin{array}{l}\text { Low } \\
\text { CAR } \\
(-2,2) \\
\end{array}$ & $\begin{array}{l}\text { High } \\
\text { CAR } \\
(-2,2) \\
\end{array}$ & $\begin{array}{l}\text { Low } \\
\text { CAR } \\
(-5,5) \\
\end{array}$ & $\begin{array}{l}\text { High } \\
\text { CAR } \\
(-5,5) \\
\end{array}$ \\
\hline CORRUPTION & $\begin{array}{l}0.031 \\
(0.16)\end{array}$ & $\begin{array}{l}0.016 \\
(0.23)\end{array}$ & $\begin{array}{l}0.073^{* *} \\
(0.03)\end{array}$ & $\begin{array}{l}0.022 \\
(0.21)\end{array}$ & $\begin{array}{l}0.071 \\
(0.12)\end{array}$ & $\begin{array}{l}0.015 \\
(0.49)\end{array}$ \\
\hline POST & $\begin{array}{l}0.054^{* * *} \\
(0.00)\end{array}$ & $\begin{array}{l}-0.001 \\
(0.92)\end{array}$ & $\begin{array}{l}0.067 * * * \\
(0.01)\end{array}$ & $\begin{array}{l}0.010 \\
(0.57)\end{array}$ & $\begin{array}{l}0.035 \\
(0.33)\end{array}$ & $\begin{array}{l}0.055^{* *} \\
(0.02)\end{array}$ \\
\hline CORP*POST & $\begin{array}{l}-0.073^{* *} \\
(0.01)\end{array}$ & $\begin{array}{l}-0.084^{* * *} \\
(0.00)\end{array}$ & $\begin{array}{l}-0.121^{* * *} \\
(0.00)\end{array}$ & $\begin{array}{l}-0.110^{* * *} \\
(0.00)\end{array}$ & $\begin{array}{l}-0.126^{* *} \\
(0.02)\end{array}$ & $\begin{array}{l}-0.125^{* * *} \\
(0.00)\end{array}$ \\
\hline RELATIVE SIZE & $\begin{array}{l}0.017^{* * *} \\
(0.00)\end{array}$ & $\begin{array}{l}0.012 \\
(0.12)\end{array}$ & $\begin{array}{l}0.020 * * * \\
(0.00)\end{array}$ & $\begin{array}{l}0.012 \\
(0.14)\end{array}$ & $\begin{array}{l}0.044^{* * *} \\
(0.00)\end{array}$ & $\begin{array}{l}-0.010 \\
(0.31)\end{array}$ \\
\hline CASH PAYMENT & $\begin{array}{l}0.006 \\
(0.81)\end{array}$ & $\begin{array}{l}-0.045^{*} \\
(0.08)\end{array}$ & $\begin{array}{l}-0.012 \\
(0.76)\end{array}$ & $\begin{array}{l}-0.069 * * \\
(0.03)\end{array}$ & $\begin{array}{l}0.018 \\
(0.76)\end{array}$ & $\begin{array}{l}-0.115^{* * *} \\
(0.00)\end{array}$ \\
\hline SIZE & $\begin{array}{l}0.001 \\
(0.93)\end{array}$ & $\begin{array}{l}0.008 \\
(0.13)\end{array}$ & $\begin{array}{l}-0.008 \\
(0.59)\end{array}$ & $\begin{array}{l}0.019 * * * \\
(0.00)\end{array}$ & $\begin{array}{l}-0.003 \\
(0.87)\end{array}$ & $\begin{array}{l}0.020^{* *} \\
(0.04)\end{array}$ \\
\hline $\mathrm{Q}$ & $\begin{array}{l}0.004 \\
(0.53)\end{array}$ & $\begin{array}{l}0.014^{* * *} \\
(0.01)\end{array}$ & $\begin{array}{l}0.010 \\
(0.24)\end{array}$ & $\begin{array}{l}0.022 * * * \\
(0.00)\end{array}$ & $\begin{array}{l}0.001 \\
(0.91)\end{array}$ & $\begin{array}{l}0.029 * * * \\
(0.00)\end{array}$ \\
\hline OPCFTA & $\begin{array}{l}-0.097^{* *} \\
(0.01)\end{array}$ & $\begin{array}{l}0.006 \\
(0.90)\end{array}$ & $\begin{array}{l}-0.106 \\
(0.14)\end{array}$ & $\begin{array}{l}0.036 \\
(0.57)\end{array}$ & $\begin{array}{l}-0.170^{*} \\
(0.09)\end{array}$ & $\begin{array}{l}0.065 \\
(0.40)\end{array}$ \\
\hline LEVERAGE & $\begin{array}{l}-0.104^{* *} \\
(0.01)\end{array}$ & $\begin{array}{l}-0.006 \\
(0.73)\end{array}$ & $\begin{array}{l}-0.112^{* *} \\
(0.04)\end{array}$ & $\begin{array}{l}-0.006 \\
(0.68)\end{array}$ & $\begin{array}{l}-0.138 \\
(0.11)\end{array}$ & $\begin{array}{l}0.021 \\
(0.31)\end{array}$ \\
\hline BOARDSIZE & $\begin{array}{l}-0.003 \\
(0.42)\end{array}$ & $\begin{array}{l}-0.003 \\
(0.48)\end{array}$ & $\begin{array}{l}0.003 \\
(0.53)\end{array}$ & $\begin{array}{l}-0.006 \\
(0.25)\end{array}$ & $\begin{array}{l}-0.002 \\
(0.71)\end{array}$ & $\begin{array}{l}-0.001 \\
(0.91)\end{array}$ \\
\hline BOARDIND & $\begin{array}{l}0.169 * \\
(0.06)\end{array}$ & $\begin{array}{l}0.144 \\
(0.17)\end{array}$ & $\begin{array}{l}0.146 \\
(0.19)\end{array}$ & $\begin{array}{l}0.073 \\
(0.63)\end{array}$ & $\begin{array}{l}0.114 \\
(0.53)\end{array}$ & $\begin{array}{l}0.057 \\
(0.79)\end{array}$ \\
\hline OWNERSHIP & $\begin{array}{l}-0.015 \\
(0.81)\end{array}$ & $\begin{array}{l}0.062 \\
(0.27)\end{array}$ & $\begin{array}{l}0.016 \\
(0.81)\end{array}$ & $\begin{array}{l}0.069 \\
(0.38)\end{array}$ & $\begin{array}{l}0.016 \\
(0.87)\end{array}$ & $\begin{array}{l}0.064 \\
(0.35)\end{array}$ \\
\hline INTERCEPT & $\begin{array}{l}0.029 \\
(0.88) \\
\end{array}$ & $\begin{array}{l}1.596^{* * * *} \\
(0.00)\end{array}$ & $\begin{array}{l}0.153 \\
(0.54) \\
\end{array}$ & $\begin{array}{l}0.683^{* * *} \\
(0.00)\end{array}$ & $\begin{array}{l}0.007 \\
(0.98) \\
\end{array}$ & $\begin{array}{l}-1.363^{* * *} \\
(0.00)\end{array}$ \\
\hline YEAR & YES & YES & YES & YES & YES & YES \\
\hline INDUSTRY & YES & YES & YES & YES & YES & YES \\
\hline $\mathrm{N}$ & 135 & 248 & 135 & 248 & 135 & 248 \\
\hline adj. R-sq & 0.52 & 0.78 & 0.55 & 0.51 & 0.61 & 0.44 \\
\hline
\end{tabular}


Panel B Firm performance: Tobin's Q

\begin{tabular}{|c|c|c|c|c|c|c|}
\hline & $\begin{array}{l}\text { Low } \\
\text { CAR } \\
(-1,1) \\
\end{array}$ & $\begin{array}{l}\text { High } \\
\text { CAR } \\
(-1,1) \\
\end{array}$ & $\begin{array}{l}\text { Low } \\
\text { CAR } \\
(-2,2) \\
\end{array}$ & $\begin{array}{l}\text { High } \\
\text { CAR } \\
(-2,2) \\
\end{array}$ & $\begin{array}{l}\text { Low } \\
\text { CAR } \\
(-5,5) \\
\end{array}$ & $\begin{array}{l}\text { High } \\
\text { CAR } \\
(-5,5) \\
\end{array}$ \\
\hline CORRUPTION & $\begin{array}{l}0.032^{*} \\
(0.07)\end{array}$ & $\begin{array}{l}0.015 \\
(0.37)\end{array}$ & $\begin{array}{l}0.046^{*} \\
(0.09)\end{array}$ & $\begin{array}{l}0.031 \\
(0.20)\end{array}$ & $\begin{array}{l}0.092^{* *} \\
(0.01)\end{array}$ & $\begin{array}{l}0.011 \\
(0.69)\end{array}$ \\
\hline POST & $\begin{array}{l}0.026 \\
(0.25)\end{array}$ & $\begin{array}{l}0.007 \\
(0.54)\end{array}$ & $\begin{array}{l}0.018 \\
(0.48)\end{array}$ & $\begin{array}{l}0.028^{*} \\
(0.06)\end{array}$ & $\begin{array}{l}0.013 \\
(0.67)\end{array}$ & $\begin{array}{l}0.049^{* *} \\
(0.03)\end{array}$ \\
\hline CORP*POST & $\begin{array}{l}-0.074^{* * *} \\
(0.00)\end{array}$ & $\begin{array}{l}-0.074^{* * *} \\
(0.00)\end{array}$ & $\begin{array}{l}-0.104^{* * *} \\
(0.01)\end{array}$ & $\begin{array}{l}-0.109 * * * \\
(0.00)\end{array}$ & $\begin{array}{l}-0.147^{* * *} \\
(0.01)\end{array}$ & $\begin{array}{l}-0.119 * * * \\
(0.01)\end{array}$ \\
\hline RELATIVE SIZE & $\begin{array}{l}-0.124 \\
(0.22)\end{array}$ & $\begin{array}{l}0.010^{* *} \\
(0.01)\end{array}$ & $\begin{array}{l}-0.188 \\
(0.17)\end{array}$ & $\begin{array}{l}0.013^{* * * *} \\
(0.01)\end{array}$ & $\begin{array}{l}-0.153 \\
(0.41)\end{array}$ & $\begin{array}{l}0.025^{* * *} \\
(0.00)\end{array}$ \\
\hline CASH PAYMENT & $\begin{array}{l}-0.019 \\
(0.46)\end{array}$ & $\begin{array}{l}-0.061^{* *} \\
(0.02)\end{array}$ & $\begin{array}{l}-0.033 \\
(0.44)\end{array}$ & $\begin{array}{l}-0.075^{* *} \\
(0.04)\end{array}$ & $\begin{array}{l}-0.046 \\
(0.44)\end{array}$ & $\begin{array}{l}-0.076 * \\
(0.05)\end{array}$ \\
\hline SIZE & $\begin{array}{l}0.007 \\
(0.28)\end{array}$ & $\begin{array}{l}0.006 \\
(0.37)\end{array}$ & $\begin{array}{l}0.015^{*} \\
(0.06)\end{array}$ & $\begin{array}{l}0.012 \\
(0.23)\end{array}$ & $\begin{array}{l}0.014 \\
(0.28)\end{array}$ & $\begin{array}{l}0.038^{* *} \\
(0.01)\end{array}$ \\
\hline $\mathrm{Q}$ & $\begin{array}{l}0.021 \\
(0.57)\end{array}$ & $\begin{array}{l}0.011^{* *} \\
(0.03)\end{array}$ & $\begin{array}{l}0.053 \\
(0.30)\end{array}$ & $\begin{array}{l}0.019 * * * \\
(0.01)\end{array}$ & $\begin{array}{l}0.150 * \\
(0.09)\end{array}$ & $\begin{array}{l}0.034^{* * *} \\
(0.00)\end{array}$ \\
\hline OPCFTA & $\begin{array}{l}-0.050 \\
(0.35)\end{array}$ & $\begin{array}{l}0.018 \\
(0.69)\end{array}$ & $\begin{array}{l}0.046 \\
(0.54)\end{array}$ & $\begin{array}{l}0.027 \\
(0.71)\end{array}$ & $\begin{array}{l}0.111 \\
(0.21)\end{array}$ & $\begin{array}{l}-0.109 \\
(0.18)\end{array}$ \\
\hline LEVERAGE & $\begin{array}{l}-0.062 \\
(0.13)\end{array}$ & $\begin{array}{l}-0.009 \\
(0.54)\end{array}$ & $\begin{array}{l}-0.087^{*} \\
(0.09)\end{array}$ & $\begin{array}{l}-0.022 \\
(0.20)\end{array}$ & $\begin{array}{l}-0.088 \\
(0.31)\end{array}$ & $\begin{array}{l}-0.029 \\
(0.31)\end{array}$ \\
\hline BOARDSIZE & $\begin{array}{l}0.002 \\
(0.47)\end{array}$ & $\begin{array}{l}-0.005 \\
(0.17)\end{array}$ & $\begin{array}{l}0.000 \\
(1.00)\end{array}$ & $\begin{array}{l}-0.002 \\
(0.70)\end{array}$ & $\begin{array}{l}0.005 \\
(0.65)\end{array}$ & $\begin{array}{l}-0.004 \\
(0.47)\end{array}$ \\
\hline BOARDIND & $\begin{array}{l}0.120 \\
(0.12)\end{array}$ & $\begin{array}{l}0.105 \\
(0.23)\end{array}$ & $\begin{array}{l}0.130 \\
(0.28)\end{array}$ & $\begin{array}{l}0.045 \\
(0.70)\end{array}$ & $\begin{array}{l}0.320 \\
(0.23)\end{array}$ & $\begin{array}{l}-0.180 \\
(0.25)\end{array}$ \\
\hline OWNERSHIP & $\begin{array}{l}0.016 \\
(0.75)\end{array}$ & $\begin{array}{l}0.071 \\
(0.24)\end{array}$ & $\begin{array}{l}0.040 \\
(0.47)\end{array}$ & $\begin{array}{l}0.052 \\
(0.53)\end{array}$ & $\begin{array}{l}-0.016 \\
(0.83)\end{array}$ & $\begin{array}{l}0.012 \\
(0.90)\end{array}$ \\
\hline INTERCEPT & $\begin{array}{l}1.522^{* * *} \\
(0.00)\end{array}$ & $\begin{array}{l}0.004 \\
(0.98)\end{array}$ & $\begin{array}{l}0.566^{* * *} \\
(0.00)\end{array}$ & $\begin{array}{l}-0.100 \\
(0.61)\end{array}$ & $\begin{array}{l}-1.645^{* * *} \\
(0.00)\end{array}$ & $\begin{array}{l}-0.549 * \\
(0.07)\end{array}$ \\
\hline YEAR & YES & YES & YES & YES & YES & YES \\
\hline INDUSTRY & YES & YES & YES & YES & YES & YES \\
\hline $\mathrm{N}$ & 155 & 228 & 155 & 228 & 155 & 228 \\
\hline adj. R-sq & 0.87 & 0.43 & 0.54 & 0.43 & 0.42 & 0.46 \\
\hline
\end{tabular}


Table 11 The impact of corruption events on the short-term post-M\&A performance of non-SOEs in regions with high and low corruption index

This table presents the regression results for the impact of corruption events on firms' short-term postM\&A performance in regions with high and low corruption index. The dependent variable is post-M\&A performance measured by CARs for three-day, five-day and 11-day windows (CAR $(-1,1)$, CAR $(-2$, 2) and CAR $(-5,5))$. 'CORRUPTION' is a dummy variable that is equal to one if a firm is a related firm, and zero otherwise. 'POST' is a dummy variable that is equal to one if the observation is obtained after the year of the corruption event, otherwise zero. The 'Low' and 'High' subsamples refer to the firm locates in the providence has corruption index which is lower and higher than the sample median value, respectively. The standard errors are clustered by firm to account for any possible correlations between firms. Standardized beta coefficients; p-values in parentheses. *, **, *** represent significance at $10 \%, 5 \%$ and $1 \%$ levels, respectively.

\begin{tabular}{|c|c|c|c|c|c|c|}
\hline & $\begin{array}{l}\text { High } \\
\text { CAR } \\
(-1,1)\end{array}$ & $\begin{array}{l}\text { Low } \\
\text { CAR } \\
(-1,1)\end{array}$ & $\begin{array}{l}\text { High } \\
\text { CAR } \\
(-2,2)\end{array}$ & $\begin{array}{l}\text { Low } \\
\text { CAR } \\
(-2,2)\end{array}$ & $\begin{array}{l}\text { High } \\
\text { CAR } \\
(-5,5)\end{array}$ & $\begin{array}{l}\text { Low } \\
\text { CAR } \\
(-5,5)\end{array}$ \\
\hline CORRUPTION & $\begin{array}{l}0.062 * * \\
(0.05)\end{array}$ & $\begin{array}{l}0.011 \\
(0.54)\end{array}$ & $\begin{array}{l}0.054^{*} \\
(0.10)\end{array}$ & $\begin{array}{l}0.024 \\
(0.32)\end{array}$ & $\begin{array}{l}-0.024 \\
(0.50)\end{array}$ & $\begin{array}{l}0.021 \\
(0.46)\end{array}$ \\
\hline POST & $\begin{array}{l}0.017 \\
(0.52)\end{array}$ & $\begin{array}{l}0.006 \\
(0.63)\end{array}$ & $\begin{array}{l}0.045^{*} \\
(0.06)\end{array}$ & $\begin{array}{l}0.009 \\
(0.49)\end{array}$ & $\begin{array}{l}0.075^{* *} \\
(0.01)\end{array}$ & $\begin{array}{l}0.017 \\
(0.36)\end{array}$ \\
\hline CORP*POST & $\begin{array}{l}-0.157^{* * *} \\
(0.00)\end{array}$ & $\begin{array}{l}-0.070^{* * *} \\
(0.00)\end{array}$ & $\begin{array}{l}-0.168^{* * *} \\
(0.00)\end{array}$ & $\begin{array}{l}-0.090^{* * *} \\
(0.00)\end{array}$ & $\begin{array}{l}-0.088 \\
(0.12)\end{array}$ & $\begin{array}{l}-0.077^{* *} \\
(0.04)\end{array}$ \\
\hline RELATIVE SIZE & $\begin{array}{l}0.014 * \\
(0.07)\end{array}$ & $\begin{array}{l}0.011^{*} \\
(0.06)\end{array}$ & $\begin{array}{l}0.016^{* * *} \\
(0.01)\end{array}$ & $\begin{array}{l}0.019 * * \\
(0.02)\end{array}$ & $\begin{array}{l}0.018^{* *} \\
(0.05)\end{array}$ & $\begin{array}{l}0.032^{* * *} \\
(0.00)\end{array}$ \\
\hline CASH PAYMENT & $\begin{array}{l}-0.016 \\
(0.62)\end{array}$ & $\begin{array}{l}-0.037 \\
(0.40)\end{array}$ & $\begin{array}{l}-0.037 \\
(0.25)\end{array}$ & $\begin{array}{l}-0.055 \\
(0.36)\end{array}$ & $\begin{array}{l}-0.082^{* *} \\
(0.03)\end{array}$ & $\begin{array}{l}-0.070 \\
(0.32)\end{array}$ \\
\hline SIZE & $\begin{array}{l}0.005 \\
(0.64)\end{array}$ & $\begin{array}{l}-0.006 \\
(0.39)\end{array}$ & $\begin{array}{l}0.020^{* *} \\
(0.02)\end{array}$ & $\begin{array}{l}-0.012 \\
(0.22)\end{array}$ & $\begin{array}{l}0.041^{* * *} \\
(0.00)\end{array}$ & $\begin{array}{l}-0.006 \\
(0.61)\end{array}$ \\
\hline Q & $\begin{array}{l}0.008 \\
(0.49)\end{array}$ & $\begin{array}{l}0.005 \\
(0.33)\end{array}$ & $\begin{array}{l}0.025^{* *} \\
(0.02)\end{array}$ & $\begin{array}{l}0.003 \\
(0.73)\end{array}$ & $\begin{array}{l}0.042^{* * *} \\
(0.00)\end{array}$ & $\begin{array}{l}0.010 \\
(0.24)\end{array}$ \\
\hline OPCFTA & $\begin{array}{l}0.033 \\
(0.75)\end{array}$ & $\begin{array}{l}-0.035 \\
(0.36)\end{array}$ & $\begin{array}{l}-0.007 \\
(0.94)\end{array}$ & $\begin{array}{l}0.016 \\
(0.74)\end{array}$ & $\begin{array}{l}-0.085 \\
(0.48)\end{array}$ & $\begin{array}{l}-0.048 \\
(0.45)\end{array}$ \\
\hline LEVERAGE & $\begin{array}{l}-0.027 \\
(0.25)\end{array}$ & $\begin{array}{l}0.013 \\
(0.69)\end{array}$ & $\begin{array}{l}-0.033^{*} \\
(0.06)\end{array}$ & $\begin{array}{l}0.018 \\
(0.55)\end{array}$ & $\begin{array}{l}-0.042 \\
(0.12)\end{array}$ & $\begin{array}{l}0.046 \\
(0.19)\end{array}$ \\
\hline BOARDSIZE & $\begin{array}{l}-0.013^{*} \\
(0.06)\end{array}$ & $\begin{array}{l}0.001 \\
(0.72)\end{array}$ & $\begin{array}{l}-0.010 \\
(0.14)\end{array}$ & $\begin{array}{l}0.008^{*} \\
(0.08)\end{array}$ & $\begin{array}{l}0.014^{*} \\
(0.08)\end{array}$ & $\begin{array}{l}0.005 \\
(0.37)\end{array}$ \\
\hline BOARDIND & $\begin{array}{l}-0.078 \\
(0.73)\end{array}$ & $\begin{array}{l}0.140 \\
(0.19)\end{array}$ & $\begin{array}{l}-0.132 \\
(0.37)\end{array}$ & $\begin{array}{l}0.142 \\
(0.30)\end{array}$ & $\begin{array}{l}0.202 \\
(0.43)\end{array}$ & $\begin{array}{l}0.034 \\
(0.83)\end{array}$ \\
\hline OWNERSHIP & $\begin{array}{l}0.040 \\
(0.75)\end{array}$ & $\begin{array}{l}0.005 \\
(0.92)\end{array}$ & $\begin{array}{l}0.111 \\
(0.17)\end{array}$ & $\begin{array}{l}-0.036 \\
(0.61)\end{array}$ & $\begin{array}{l}0.122 \\
(0.39)\end{array}$ & $\begin{array}{l}-0.034 \\
(0.61)\end{array}$ \\
\hline INTERCEPT & $\begin{array}{l}0.409^{*} \\
(0.10)\end{array}$ & $\begin{array}{l}0.095 \\
(0.53) \\
\end{array}$ & $\begin{array}{l}-0.070 \\
(0.80)\end{array}$ & $\begin{array}{l}0.223 \\
(0.24)\end{array}$ & $\begin{array}{l}-1.158^{* * *} \\
(0.00)\end{array}$ & $\begin{array}{l}0.119 \\
(0.63)\end{array}$ \\
\hline $\begin{array}{l}\text { F-test: equal } \\
\text { CORP*POST }\end{array}$ & \multicolumn{2}{|c|}{$\begin{array}{c}-0.087 * \\
(0.07)\end{array}$} & \multicolumn{2}{|c|}{$\begin{array}{c}-0.078^{*} \\
(0.09)\end{array}$} & \multicolumn{2}{|c|}{$\begin{array}{l}0.011 \\
(0.36)\end{array}$} \\
\hline YEAR & YES & YES & YES & YES & YES & YES \\
\hline INDUSTRY & YES & YES & YES & YES & YES & YES \\
\hline $\mathrm{N}$ & 196 & 187 & 196 & 187 & 196 & 187 \\
\hline adj. R-sq & 0.24 & 0.40 & 0.37 & 0.40 & 0.36 & 0.45 \\
\hline
\end{tabular}


Table 12 The impact of corruption events on the short-term post-M\&A performance of non-SOEs across industries

This table presents the regression results for the impact of corruption events on the short-term post-M\&A performance of non-SOEs that operate in supported or non-supported industries (Panel A), highly competitive or less competitive industries (Panel B). In Panel A, the 'Supported' and 'Non-supported' subsamples refer to the firm belonging to government-supported industries and non-government-supported industries. In Panel B, the 'High' and 'Low' subsamples refer to the firm belonging to less competitive industries and highly competitive industries. The dependent variable is post-M\&A performance measured by CARs for three-day, five-day and 11-day windows (CAR $(-1,1)$, CAR $(-2,2)$ and CAR $(-5,5))$. 'CORRUPTION' is a dummy variable that is equal to one if a firm is a related firm, and zero otherwise. 'POST' is a dummy variable that is equal to one if the observation is obtained after the year of the corruption event, otherwise zero. The standard errors are clustered by firm to account for any possible correlations between firms. Standardized beta coefficients; p-values in parentheses.

$*, * *, * * *$ represent significance at $10 \%, 5 \%$ and $1 \%$ levels, respectively.

Panel A Government-supported versus non-government-supported industries

\begin{tabular}{|c|c|c|c|c|c|c|}
\hline & $\begin{array}{l}\text { Supported } \\
\text { CAR }(-1,1)\end{array}$ & $\begin{array}{l}\text { Non-supported } \\
\text { CAR }(-1,1)\end{array}$ & $\begin{array}{l}\text { Supported } \\
\text { CAR }(-2,2)\end{array}$ & $\begin{array}{l}\text { Non-supported } \\
\text { CAR }(-2,2) \\
\end{array}$ & $\begin{array}{l}\text { Supported } \\
\text { CAR }(-5,5)\end{array}$ & $\begin{array}{l}\text { Non-supported } \\
\text { CAR }(-5,5)\end{array}$ \\
\hline CORRUPTION & $\begin{array}{l}0.252^{* *} \\
(0.01)\end{array}$ & $\begin{array}{l}0.008 \\
(0.56)\end{array}$ & $\begin{array}{l}0.209 * * \\
(0.05)\end{array}$ & $\begin{array}{l}0.019 \\
(0.31)\end{array}$ & $\begin{array}{l}0.005 \\
(0.97)\end{array}$ & $\begin{array}{l}0.000 \\
(0.98)\end{array}$ \\
\hline POST & $\begin{array}{l}0.069 \\
(0.39)\end{array}$ & $\begin{array}{l}0.014 \\
(0.23)\end{array}$ & $\begin{array}{l}0.054 \\
(0.17)\end{array}$ & $\begin{array}{l}0.031^{* *} \\
(0.04)\end{array}$ & $\begin{array}{l}0.050 \\
(0.28)\end{array}$ & $\begin{array}{l}0.044^{* *} \\
(0.04)\end{array}$ \\
\hline CORP*POST & $\begin{array}{l}-0.362^{* * *} \\
(0.01)\end{array}$ & $\begin{array}{l}-0.072^{* * *} \\
(0.00)\end{array}$ & $\begin{array}{l}-0.295^{* *} \\
(0.04)\end{array}$ & $\begin{array}{l}-0.107^{* * *} \\
(0.00)\end{array}$ & $\begin{array}{l}0.004 \\
(0.98)\end{array}$ & $\begin{array}{l}-0.108^{* * *} \\
(0.01)\end{array}$ \\
\hline RELATIVE SIZE & $\begin{array}{l}0.182 \\
(0.44)\end{array}$ & $\begin{array}{l}0.013^{* * *} \\
(0.00)\end{array}$ & $\begin{array}{l}0.166 \\
(0.34)\end{array}$ & $\begin{array}{l}0.017^{* * *} \\
(0.00)\end{array}$ & $\begin{array}{l}0.012 \\
(0.92)\end{array}$ & $\begin{array}{l}0.026^{* * *} \\
(0.00)\end{array}$ \\
\hline CASH PAYMENT & $\begin{array}{l}-0.006 \\
(0.95)\end{array}$ & $\begin{array}{l}-0.030 \\
(0.14)\end{array}$ & $\begin{array}{l}-0.045 \\
(0.51)\end{array}$ & $\begin{array}{l}-0.044 \\
(0.12)\end{array}$ & $\begin{array}{l}-0.139 * \\
(0.06)\end{array}$ & $\begin{array}{l}-0.054 \\
(0.12)\end{array}$ \\
\hline SIZE & $\begin{array}{l}-0.002 \\
(0.96)\end{array}$ & $\begin{array}{l}0.006 \\
(0.27)\end{array}$ & $\begin{array}{l}0.025 \\
(0.27)\end{array}$ & $\begin{array}{l}0.012 \\
(0.12)\end{array}$ & $\begin{array}{l}0.066^{* *} \\
(0.04)\end{array}$ & $\begin{array}{l}0.029^{* *} \\
(0.02)\end{array}$ \\
\hline $\mathrm{Q}$ & $\begin{array}{l}0.013 \\
(0.73)\end{array}$ & $\begin{array}{l}0.010^{* *} \\
(0.03)\end{array}$ & $\begin{array}{l}0.029 * \\
(0.09)\end{array}$ & $\begin{array}{l}0.016^{* *} \\
(0.01)\end{array}$ & $\begin{array}{l}0.034 \\
(0.16)\end{array}$ & $\begin{array}{l}0.029 * * * \\
(0.00)\end{array}$ \\
\hline OPCFTA & $\begin{array}{l}-0.040 \\
(0.94)\end{array}$ & $\begin{array}{l}-0.011 \\
(0.73)\end{array}$ & $\begin{array}{l}-0.065 \\
(0.78)\end{array}$ & $\begin{array}{l}0.004 \\
(0.93)\end{array}$ & $\begin{array}{l}-0.203 \\
(0.49)\end{array}$ & $\begin{array}{l}-0.058 \\
(0.36)\end{array}$ \\
\hline LEVERAGE & $\begin{array}{l}0.108 \\
(0.57)\end{array}$ & $\begin{array}{l}-0.008 \\
(0.55)\end{array}$ & $\begin{array}{l}-0.005 \\
(0.97)\end{array}$ & $\begin{array}{l}-0.021 \\
(0.22)\end{array}$ & $\begin{array}{l}-0.309 * \\
(0.09)\end{array}$ & $\begin{array}{l}-0.029 \\
(0.34)\end{array}$ \\
\hline BOARDSIZE & -0.025 & -0.003 & -0.017 & -0.001 & 0.011 & 0.001 \\
\hline
\end{tabular}




\begin{tabular}{|c|c|c|c|c|c|c|}
\hline & $(0.15)$ & $(0.32)$ & $(0.16)$ & $(0.78)$ & $(0.45)$ & $(0.82)$ \\
\hline \multirow[t]{2}{*}{ BOARDIND } & -0.201 & 0.096 & 0.196 & 0.047 & $0.795^{*}$ & -0.036 \\
\hline & $(0.74)$ & $(0.15)$ & $(0.58)$ & $(0.61)$ & $(0.05)$ & $(0.80)$ \\
\hline \multirow[t]{2}{*}{ OWNERSHIP } & 0.115 & $0.112 * *$ & 0.008 & $0.124^{* *}$ & -0.054 & 0.040 \\
\hline & $(0.70)$ & $(0.04)$ & $(0.96)$ & $(0.04)$ & $(0.70)$ & $(0.57)$ \\
\hline \multirow[t]{2}{*}{ INTERCEPT } & 0.475 & -0.070 & -0.335 & -0.173 & $-1.553^{*}$ & $-0.559 * *$ \\
\hline & $(0.55)$ & $(0.53)$ & $(0.56)$ & $(0.27)$ & $(0.05)$ & $(0.04)$ \\
\hline F-test: equal & \multicolumn{2}{|r|}{$-0.290 * * *$} & \multicolumn{2}{|r|}{$-0.188 * *$} & \multicolumn{2}{|c|}{0.104} \\
\hline CORP*POST & \multicolumn{2}{|r|}{$(0.00)$} & \multicolumn{2}{|r|}{$(0.03)$} & \multicolumn{2}{|c|}{$(0.74)$} \\
\hline YEAR & YES & YES & YES & YES & YES & YES \\
\hline INDUSTRY & YES & YES & YES & YES & YES & YES \\
\hline $\mathrm{N}$ & 76 & 307 & 76 & 307 & 76 & 307 \\
\hline adj. R-sq & 0.11 & 0.39 & 0.22 & 0.38 & 0.18 & 0.36 \\
\hline
\end{tabular}


Panel B Highly competitive versus less competitive industries

\begin{tabular}{|c|c|c|c|c|c|c|}
\hline & $\begin{array}{l}\text { High } \\
\text { CAR } \\
(-1,1) \\
\end{array}$ & $\begin{array}{l}\text { Low } \\
\text { CAR } \\
(-1,1) \\
\end{array}$ & $\begin{array}{l}\text { High } \\
\text { CAR } \\
(-2,2) \\
\end{array}$ & $\begin{array}{l}\text { Low } \\
\text { CAR } \\
(-2,2) \\
\end{array}$ & $\begin{array}{l}\text { High } \\
\text { CAR } \\
(-5,5) \\
\end{array}$ & $\begin{array}{l}\text { Low } \\
\text { CAR } \\
(-5,5) \\
\end{array}$ \\
\hline CORRUPTION & $\begin{array}{l}0.012 \\
(0.52)\end{array}$ & $\begin{array}{l}0.138 \\
(0.12)\end{array}$ & $\begin{array}{l}0.019 \\
(0.35)\end{array}$ & $\begin{array}{l}0.108^{* *} \\
(0.05)\end{array}$ & $\begin{array}{l}0.021 \\
(0.46)\end{array}$ & $\begin{array}{l}-0.061 \\
(0.13)\end{array}$ \\
\hline POST & $\begin{array}{l}0.027^{*} \\
(0.06)\end{array}$ & $\begin{array}{l}0.011 \\
(0.58)\end{array}$ & $\begin{array}{l}0.049 * * \\
(0.02)\end{array}$ & $\begin{array}{l}0.015 \\
(0.41)\end{array}$ & $\begin{array}{l}0.055^{* *} \\
(0.05)\end{array}$ & $\begin{array}{l}0.038 \\
(0.19)\end{array}$ \\
\hline CORP*POST & $\begin{array}{l}-0.068^{* * *} \\
(0.00)\end{array}$ & $\begin{array}{l}-0.196^{* *} \\
(0.04)\end{array}$ & $\begin{array}{l}-0.087^{* * *} \\
(0.00)\end{array}$ & $\begin{array}{l}-0.199 * * * \\
(0.00)\end{array}$ & $\begin{array}{l}-0.085^{* *} \\
(0.04)\end{array}$ & $\begin{array}{l}-0.075 \\
(0.19)\end{array}$ \\
\hline RELATIVE SIZE & $\begin{array}{l}0.015^{* * *} \\
(0.00)\end{array}$ & $\begin{array}{l}0.015^{* *} \\
(0.02)\end{array}$ & $\begin{array}{l}0.019 * * * \\
(0.00)\end{array}$ & $\begin{array}{l}0.020^{* * *} \\
(0.01)\end{array}$ & $\begin{array}{l}0.028^{* * *} \\
(0.00)\end{array}$ & $\begin{array}{l}0.033^{* * *} \\
(0.00)\end{array}$ \\
\hline CASH PAYMENT & $\begin{array}{l}-0.009 \\
(0.77)\end{array}$ & $\begin{array}{l}-0.044 \\
(0.19)\end{array}$ & $\begin{array}{l}-0.019 \\
(0.58)\end{array}$ & $\begin{array}{l}-0.068 \\
(0.11)\end{array}$ & $\begin{array}{l}-0.036 \\
(0.45)\end{array}$ & $\begin{array}{l}-0.087^{* *} \\
(0.03)\end{array}$ \\
\hline SIZE & $\begin{array}{l}0.001 \\
(0.90)\end{array}$ & $\begin{array}{l}0.005 \\
(0.66)\end{array}$ & $\begin{array}{l}0.007 \\
(0.37)\end{array}$ & $\begin{array}{l}0.008 \\
(0.56)\end{array}$ & $\begin{array}{l}0.020^{*} \\
(0.05)\end{array}$ & $\begin{array}{l}0.012 \\
(0.40)\end{array}$ \\
\hline Q & $\begin{array}{l}0.010^{* *} \\
(0.05)\end{array}$ & $\begin{array}{l}-0.004 \\
(0.68)\end{array}$ & $\begin{array}{l}0.017^{* *} \\
(0.02)\end{array}$ & $\begin{array}{l}0.001 \\
(0.91)\end{array}$ & $\begin{array}{l}0.034^{* * *} \\
(0.00)\end{array}$ & $\begin{array}{l}0.008 \\
(0.53)\end{array}$ \\
\hline OPCFTA & $\begin{array}{l}-0.036 \\
(0.49)\end{array}$ & $\begin{array}{l}0.108 \\
(0.16)\end{array}$ & $\begin{array}{l}0.000 \\
(1.00)\end{array}$ & $\begin{array}{l}0.120 \\
(0.13)\end{array}$ & $\begin{array}{l}-0.017 \\
(0.84)\end{array}$ & $\begin{array}{l}-0.030 \\
(0.78)\end{array}$ \\
\hline LEVERAGE & $\begin{array}{l}0.015 \\
(0.51)\end{array}$ & $\begin{array}{l}-0.088^{*} \\
(0.06)\end{array}$ & $\begin{array}{l}0.015 \\
(0.40)\end{array}$ & $\begin{array}{l}-0.079 \\
(0.16)\end{array}$ & $\begin{array}{l}0.014 \\
(0.46)\end{array}$ & $\begin{array}{l}-0.017 \\
(0.82)\end{array}$ \\
\hline BOARDSIZE & $\begin{array}{l}-0.004 \\
(0.38)\end{array}$ & $\begin{array}{l}-0.008 \\
(0.23)\end{array}$ & $\begin{array}{l}-0.003 \\
(0.56)\end{array}$ & $\begin{array}{l}-0.006 \\
(0.31)\end{array}$ & $\begin{array}{l}-0.006 \\
(0.24)\end{array}$ & $\begin{array}{l}0.014^{* *} \\
(0.05)\end{array}$ \\
\hline BOARDIND & $\begin{array}{l}0.284^{* *} \\
(0.01)\end{array}$ & $\begin{array}{l}-0.184 \\
(0.13)\end{array}$ & $\begin{array}{l}0.245^{* *} \\
(0.04)\end{array}$ & $\begin{array}{l}-0.185 \\
(0.11)\end{array}$ & $\begin{array}{l}0.158 \\
(0.32)\end{array}$ & $\begin{array}{l}0.042 \\
(0.84)\end{array}$ \\
\hline OWNERSHIP & $\begin{array}{l}-0.004 \\
(0.96)\end{array}$ & $\begin{array}{l}-0.001 \\
(0.98)\end{array}$ & $\begin{array}{l}-0.021 \\
(0.86)\end{array}$ & $\begin{array}{l}-0.009 \\
(0.87)\end{array}$ & $\begin{array}{l}0.146^{*} \\
(0.09)\end{array}$ & $\begin{array}{l}-0.070 \\
(0.50)\end{array}$ \\
\hline INTERCEPT & $\begin{array}{l}-0.055 \\
(0.71)\end{array}$ & $\begin{array}{l}0.437 \\
(0.36)\end{array}$ & $\begin{array}{l}-0.178 \\
(0.32) \\
\end{array}$ & $\begin{array}{l}0.216 \\
(0.54)\end{array}$ & $\begin{array}{l}-0.439 * \\
(0.09)\end{array}$ & $\begin{array}{l}-0.475 \\
(0.12)\end{array}$ \\
\hline $\begin{array}{l}\text { F-test: equal } \\
\text { CORP*POST }\end{array}$ & \multicolumn{2}{|c|}{$\begin{array}{l}0.128^{*} \\
(0.10)\end{array}$} & \multicolumn{2}{|c|}{$\begin{array}{c}0.112^{* *} \\
(0.03)\end{array}$} & \multicolumn{2}{|c|}{$\begin{array}{l}-0.010 \\
(0.74) \\
\end{array}$} \\
\hline YEAR & YES & YES & YES & YES & YES & YES \\
\hline INDUSTRY & YES & YES & YES & YES & YES & YES \\
\hline $\mathrm{N}$ & 206 & 175 & 206 & 175 & 206 & 175 \\
\hline adj. R-sq & 0.30 & 0.30 & 0.35 & 0.38 & 0.44 & 0.42 \\
\hline
\end{tabular}


Table 13 Regression results for the impact of corruption events on firms’ post-M\&A performance

This table presents the regression results for the impact of corruption events on firms' post-M\&A performance in the subsamples alternately stratified by target firms' ownership structure. The sample is partitioned alternately by whether the target firm is controlled by the state. The 'SOE Target' and 'Non-SOE Target' subsamples refer to the target firms being controlled by state and individual or private enterprises. The dependent variable is post-M\&A performance measured by CARs for three-day, five-day and 11-day windows (CAR $(-1,1)$, CAR $(-2,2)$ and CAR $(-5,5))$. 'CORRUPTION' is a dummy variable that equals one if a firm is a related firm, and zero otherwise. 'POST' is a dummy variable that is equal to one if the observation is obtained after the year of the corruption event, otherwise zero. 'CORP*POST' is the interaction between 'CORRUPTION' and 'POST'. Definition of control variables is in Appendix B, and the standard errors are clustered by firm to account for any possible correlations between firms. Standardized beta coefficients; p-values in parentheses. *, **, *** represent significance at $10 \%, 5 \%$ and $1 \%$ levels, respectively.

\begin{tabular}{|c|c|c|c|c|c|c|}
\hline & $\begin{array}{l}\text { SOE Target } \\
\text { CAR }(-1,1)\end{array}$ & $\begin{array}{l}\text { Non-SOE Target } \\
\text { CAR }(-1,1)\end{array}$ & $\begin{array}{l}\text { SOE Target } \\
\text { CAR }(-2,2)\end{array}$ & $\begin{array}{l}\text { Non-SOE Target } \\
\text { CAR }(-2,2)\end{array}$ & $\begin{array}{l}\text { SOE Target } \\
\text { CAR }(-5,5)\end{array}$ & $\begin{array}{l}\text { Non-SOE Target } \\
\text { CAR }(-5,5)\end{array}$ \\
\hline CORRUPTION & $\begin{array}{l}0.04 * \\
(0.09)\end{array}$ & $\begin{array}{l}0.06 \\
(0.12)\end{array}$ & $\begin{array}{l}0.09 * * \\
(0.02)\end{array}$ & $\begin{array}{l}0.05 * * \\
(0.05)\end{array}$ & $\begin{array}{l}0.12^{* *} \\
(0.02)\end{array}$ & $\begin{array}{l}-0.02 \\
(0.50)\end{array}$ \\
\hline POST & $\begin{array}{l}0.09 * \\
(0.09)\end{array}$ & $\begin{array}{l}0.01 \\
(0.55)\end{array}$ & $\begin{array}{l}0.13^{*} \\
(0.10)\end{array}$ & $\begin{array}{l}0.03^{*} \\
(0.08)\end{array}$ & $\begin{array}{l}0.14 \\
(0.12)\end{array}$ & $\begin{array}{l}0.05^{* *} \\
(0.02)\end{array}$ \\
\hline CORP*POST & $\begin{array}{l}-0.21^{* * *} \\
(0.00)\end{array}$ & $\begin{array}{l}-0.13^{* *} \\
(0.02)\end{array}$ & $\begin{array}{l}-0.30^{* * * *} \\
(0.00)\end{array}$ & $\begin{array}{l}-0.13^{* * *} \\
(0.00)\end{array}$ & $\begin{array}{l}-0.31^{* *} \\
(0.01)\end{array}$ & $\begin{array}{l}-0.06 \\
(0.21)\end{array}$ \\
\hline RELATIVE SIZE & $\begin{array}{l}0.38 \\
(0.28)\end{array}$ & $\begin{array}{l}0.01^{* * *} \\
(0.00)\end{array}$ & $\begin{array}{l}0.13 \\
(0.84)\end{array}$ & $\begin{array}{l}0.02^{* * *} \\
(0.00)\end{array}$ & $\begin{array}{l}-0.11 \\
(0.87)\end{array}$ & $\begin{array}{l}0.03^{* * *} \\
(0.00)\end{array}$ \\
\hline CASH PAYMENT & $\begin{array}{l}1.08 \\
(0.33)\end{array}$ & $\begin{array}{l}-0.03 \\
(0.23)\end{array}$ & $\begin{array}{l}0.22 \\
(0.91)\end{array}$ & $\begin{array}{l}-0.05^{*} \\
(0.07)\end{array}$ & $\begin{array}{l}-0.46 \\
(0.82)\end{array}$ & $\begin{array}{l}-0.07^{* *} \\
(0.03)\end{array}$ \\
\hline SIZE & $\begin{array}{l}0.00 \\
(0.97)\end{array}$ & $\begin{array}{l}0.00 \\
(0.47)\end{array}$ & $\begin{array}{l}-0.02 \\
(0.26)\end{array}$ & $\begin{array}{l}0.02^{* * *} \\
(0.00)\end{array}$ & $\begin{array}{l}-0.01 \\
(0.55)\end{array}$ & $\begin{array}{l}0.03^{* * *} \\
(0.00)\end{array}$ \\
\hline Q & $\begin{array}{l}0.05^{* *} \\
(0.02)\end{array}$ & $\begin{array}{l}0.01^{*} \\
(0.08)\end{array}$ & $\begin{array}{l}0.05 \\
(0.13)\end{array}$ & $\begin{array}{l}0.02 * * * \\
(0.01)\end{array}$ & $\begin{array}{l}0.07^{*} \\
(0.07)\end{array}$ & $\begin{array}{l}0.03^{* * *} \\
(0.00)\end{array}$ \\
\hline OPCFTA & $\begin{array}{l}-0.05 \\
(0.70)\end{array}$ & $\begin{array}{l}0.01 \\
(0.82)\end{array}$ & $\begin{array}{l}0.47^{*} \\
(0.07)\end{array}$ & $\begin{array}{l}-0.00 \\
(0.93)\end{array}$ & $\begin{array}{l}0.33 \\
(0.16)\end{array}$ & $\begin{array}{l}-0.11 \\
(0.11)\end{array}$ \\
\hline LEVERAGE & $\begin{array}{l}0.13^{*} \\
(0.09)\end{array}$ & $\begin{array}{l}-0.02 \\
(0.25)\end{array}$ & $\begin{array}{l}0.11 \\
(0.34)\end{array}$ & $\begin{array}{l}-0.03^{*} \\
(0.07)\end{array}$ & $\begin{array}{l}0.16 \\
(0.17)\end{array}$ & $\begin{array}{l}-0.04 \\
(0.17)\end{array}$ \\
\hline BOARDSIZE & $\begin{array}{l}-0.00 \\
(0.84)\end{array}$ & $\begin{array}{l}-0.01 * \\
(0.07)\end{array}$ & $\begin{array}{l}0.02 \\
(0.30)\end{array}$ & $\begin{array}{l}-0.01^{*} \\
(0.10)\end{array}$ & $\begin{array}{l}0.02 \\
(0.14)\end{array}$ & $\begin{array}{l}0.00 \\
(0.93)\end{array}$ \\
\hline
\end{tabular}




\begin{tabular}{|c|c|c|c|c|c|c|}
\hline BOARDIND & $\begin{array}{l}-0.31 \\
(0.21)\end{array}$ & $\begin{array}{l}0.01 \\
(0.93)\end{array}$ & $\begin{array}{l}-0.93 * \\
(0.05)\end{array}$ & $\begin{array}{l}0.00 \\
(0.97)\end{array}$ & $\begin{array}{l}-1.73 * * \\
(0.02)\end{array}$ & $\begin{array}{l}0.08 \\
(0.53)\end{array}$ \\
\hline OWNERSHIP & $\begin{array}{l}0.18 \\
(0.26)\end{array}$ & $\begin{array}{l}0.05 \\
(0.33)\end{array}$ & $\begin{array}{l}-0.14 \\
(0.58)\end{array}$ & $\begin{array}{l}0.07 \\
(0.25)\end{array}$ & $\begin{array}{l}0.02 \\
(0.91)\end{array}$ & $\begin{array}{l}0.04 \\
(0.48)\end{array}$ \\
\hline INTERCEPT & $\begin{array}{l}-1.20 \\
(0.34)\end{array}$ & $\begin{array}{l}0.35 \\
(0.29)\end{array}$ & $\begin{array}{l}0.18 \\
(0.94)\end{array}$ & $\begin{array}{l}-0.06 \\
(0.80)\end{array}$ & $\begin{array}{l}1.03 \\
(0.65)\end{array}$ & $\begin{array}{l}-0.88 * * * \\
(0.00)\end{array}$ \\
\hline $\begin{array}{l}\text { F-test: equal } \\
\text { CORP*POST }\end{array}$ & & $\begin{array}{l}-0.08 \\
(0.24)\end{array}$ & & $\begin{array}{l}-0.17^{* *} \\
(0.02)\end{array}$ & & $\begin{array}{c}-0.25^{* * *} \\
(0.01)\end{array}$ \\
\hline YEAR & YES & YES & YES & YES & YES & YES \\
\hline INDUSTRY & YES & YES & YES & YES & YES & YES \\
\hline $\mathrm{N}$ & 46 & 337 & 46 & 337 & 46 & 337 \\
\hline adj. R-sq & 0.52 & 0.27 & 0.48 & 0.38 & 0.50 & 0.38 \\
\hline
\end{tabular}


Table 14 The regression results for the impact of corruption events on the likelihood that the M\&A is financed by external funds

This table presents logistic regression results for the impact of corruption events on the likelihood that the M\&A deal is financed by external funds. The dependent variable 'External Financing' is binary where 1 signifies that the M\&A deal is financed externally by bank loan, corporate bonds and shares, and zero signifies that the M\&A is financed by the firm's internal fund. 'CORRUPTION' is a dummy variable that is equal to one if a firm is a related firm, and zero otherwise. 'POST' is a dummy variable that is equal to one if the observation is obtained after the year of the corruption event, otherwise zero. 'CORP*POST' is the interaction between 'CORRUPTION' and 'POST'. Control variables are defined in Appendix B and the regression is clustered by firms. The value reported is the marginal effect of independent variables; p-values in parentheses. *, **, *** represent significance at $10 \%, 5 \%$ and $1 \%$ levels, respectively.

\begin{tabular}{ll}
\hline & External Financing \\
\hline CORRUPTION & $0.170^{* *}$ \\
POST & $(0.01)$ \\
& 0.007 \\
CORP*POST & $(0.88)$ \\
& $-0.106^{* *}$ \\
SIZE & $(0.04)$ \\
Q & -0.017 \\
& $(0.27)$ \\
OPCFTA & 0.011 \\
& $(0.50)$ \\
LEVERAGE & -0.117 \\
BOARDSIZE & $(0.49)$ \\
& -0.043 \\
BOARDIND & $(0.38)$ \\
OWNERSHIP & 0.004 \\
INTERCEPT & $(0.61)$ \\
YEAR & $-0.674^{*}$ \\
INDUSTRY & $(0.06)$ \\
N & -0.225 \\
& $(0.38)$ \\
& 4.28 \\
& $(0.34)$ \\
\hline & YES \\
YES & 328 \\
& 0.14 \\
\hline
\end{tabular}


Table 15 Regression results for the impact of corruption events on corporate investment of non-SOEs

This table presents the regression results for the impact of corruption events on corporate investment expenditure of non-SOEs. 'FULL' includes all listed firms in the Shenzhen and Shanghai stock exchanges and 'JURISDICTION' only includes firms under corrupt bureaucrats' jurisdiction. The dependent variable 'CAPEXTA' is the ratio of capital expenditure to total assets. 'CORRUPTION' is a dummy variable that is equal to one if a firm is a related firm, and zero otherwise. 'POST' is a dummy variable that is equal to one if the observation is obtained after the year of the corruption event, otherwise zero. The standard errors are clustered by firm to account for any possible correlations between firms. Standardized beta coefficients; p-values in parentheses. *, **, *** represent significance at $10 \%, 5 \%$ and $1 \%$ levels, respectively.

\begin{tabular}{|c|c|c|c|c|}
\hline & \multicolumn{2}{|c|}{ Corruption related sample } & \multicolumn{2}{|c|}{ Bureaucrats connecting sample } \\
\hline & FULL & JURISDICTION & FULL & JURISDICTION \\
\hline & $\begin{array}{l}\text { CAPEXTA } \\
\end{array}$ & CAPEXTA & CAPEXTA & CAPEXTA \\
\hline \multirow{2}{*}{ CORRUPTION $_{\mathrm{t}-1}$} & $0.013^{* * *}$ & $0.016^{* * *}$ & $0.015^{* * *}$ & $0.017 * * *$ \\
\hline & $(0.00)$ & $(0.01)$ & $(0.00)$ & $(0.01)$ \\
\hline \multirow[t]{2}{*}{$\operatorname{POST}_{\mathrm{t}-1}$} & -0.002 & 0.000 & -0.002 & 0.000 \\
\hline & $(0.45)$ & $(0.93)$ & $(0.53)$ & $(0.93)$ \\
\hline \multirow[t]{2}{*}{ CORRUPTION $_{\mathrm{t}-1} *$ POST $_{\mathrm{t}-1}$} & $-0.012^{* *}$ & $-0.016 * * *$ & $-0.018^{* * *}$ & $-0.020 * * *$ \\
\hline & $(0.04)$ & $(0.01)$ & $(0.00)$ & $(0.00)$ \\
\hline \multirow[t]{2}{*}{ OPCFTA $_{t-1}$} & 0.016 & 0.017 & 0.016 & 0.018 \\
\hline & $(0.10)$ & $(0.13)$ & $(0.10)$ & $(0.13)$ \\
\hline \multirow[t]{2}{*}{$\mathrm{Q}_{\mathrm{t}-1}$} & $0.002 *$ & 0.001 & 0.002 & 0.001 \\
\hline & $(0.08)$ & $(0.20)$ & $(0.12)$ & $(0.20)$ \\
\hline \multirow[t]{2}{*}{ LEVERAGE $_{\mathrm{t}-1}$} & 0.000 & -0.000 & 0.000 & -0.000 \\
\hline & $(0.28)$ & $(1.00)$ & $(0.35)$ & $(0.66)$ \\
\hline \multirow[t]{2}{*}{ SIZE $_{\mathrm{t}-1}$} & $0.005^{* * *}$ & $0.004^{* *}$ & $0.004^{* * *}$ & $0.003^{* *}$ \\
\hline & $(0.00)$ & $(0.02)$ & $(0.00)$ & $(0.03)$ \\
\hline \multirow[t]{2}{*}{$\mathrm{SEO}_{\mathrm{t}-1}$} & 0.000 & 0.000 & 0.000 & 0.000 \\
\hline & $(0.38)$ & $(0.71)$ & $(0.45)$ & $(0.74)$ \\
\hline \multirow[t]{2}{*}{$\mathrm{AGE}_{\mathrm{t}-1}$} & $-0.004^{* * *}$ & $-0.005^{* * *}$ & $-0.004^{* * *}$ & $-0.005^{* * *}$ \\
\hline & $(0.00)$ & $(0.00)$ & $(0.00)$ & $(0.00)$ \\
\hline \multirow[t]{2}{*}{ INTERCEPT } & -0.022 & 0.024 & -0.017 & 0.031 \\
\hline & $(0.46)$ & $(0.50)$ & $(0.57)$ & $(0.39)$ \\
\hline YEAR & YES & YES & YES & YES \\
\hline INDUSTRY & YES & YES & YES & YES \\
\hline $\mathrm{N}$ & 3802 & 2899 & 3687 & 2850 \\
\hline adj. R-sq & 0.22 & 0.26 & 0.22 & 0.26 \\
\hline
\end{tabular}


Table 16 Regression results for the impact of corruption events on the corporate investment efficiency of non-SOEs

This table presents the regression results for the impact of corruption events on the corporate investment efficiency of non-SOEs. 'FULL' includes all listed firms in the Shenzhen and Shanghai stock exchanges and 'JURISDICTION' only includes firms under corrupt bureaucrats' jurisdiction. 'Before' and 'Post' refer to the sample period before and after the corruption event. The dependent variable 'CAPEXTA' is the ratio of capital expenditure to total assets. 'CORRUPTION' is a dummy variable that is equal to one if a firm is a related firm, and zero otherwise. 'Q' is Tobin's $Q$ measuring firms' investment opportunity. 'CORP $\mathrm{t}_{-1} * \mathrm{Q}_{\mathrm{t}-1}$ ' is the interaction between 'CORRUPTION ${ }_{\mathrm{t}-1}$ ' and ' $\mathrm{Q} \mathrm{t}-\mathrm{t}$ '. The standard errors are clustered by firm to account for any possible correlations between firms. Standardized beta coefficients; p-values in parentheses. *, **, *** represent significance at $10 \%, 5 \%$ and $1 \%$ levels, respectively.

\begin{tabular}{|c|c|c|c|c|c|c|c|c|}
\hline & \multicolumn{4}{|c|}{ Corruption related sample } & \multicolumn{4}{|c|}{ Bureaucrats connecting sample } \\
\hline & \multicolumn{2}{|c|}{ FULL } & \multicolumn{2}{|c|}{ JURISDICTION } & \multicolumn{2}{|c|}{ FULL } & \multicolumn{2}{|c|}{ JURISDICTION } \\
\hline & Before & Post & Before & Post & Before & Post & Before & Post \\
\hline & CAPEXTA & CAPEXTA & CAPEXTA & CAPEXTA & CAPEXTA & CAPEXTA & CAPEXTA & CAPEXTA \\
\hline \multirow{2}{*}{ CORRUPTION $_{\mathrm{t}-1}$} & 0.004 & $0.014^{* *}$ & $0.026^{* *}$ & $0.014^{* *}$ & 0.006 & $0.013^{*}$ & $0.027^{* *}$ & $0.012^{*}$ \\
\hline & $(0.73)$ & $(0.04)$ & $(0.02)$ & $(0.03)$ & $(0.64)$ & $(0.06)$ & $(0.02)$ & $(0.08)$ \\
\hline \multirow[t]{2}{*}{$Q_{t-1}$} & $0.006^{* * *}$ & 0.001 & $0.010^{* *}$ & 0.001 & $0.006^{* * *}$ & 0.001 & $0.010^{* *}$ & 0.001 \\
\hline & $(0.01)$ & $(0.48)$ & $(0.01)$ & $(0.49)$ & $(0.01)$ & $(0.52)$ & $(0.01)$ & $(0.51)$ \\
\hline \multirow[t]{2}{*}{$\operatorname{CORP}_{\mathrm{t}-1} * \mathrm{Q}_{\mathrm{t}-1}$} & 0.008 & $-0.004 * *$ & -0.007 & $-0.006 * * *$ & 0.008 & $-0.005^{* * *}$ & -0.006 & $-0.006 * * *$ \\
\hline & $(0.25)$ & $(0.03)$ & $(0.30)$ & $(0.00)$ & $(0.29)$ & $(0.01)$ & $(0.41)$ & $(0.00)$ \\
\hline \multirow[t]{2}{*}{ OPCFTA $_{\mathrm{t}-1}$} & 0.030 & 0.012 & $0.101^{* * *}$ & 0.012 & 0.030 & 0.012 & $0.114^{* * *}$ & 0.012 \\
\hline & $(0.24)$ & $(0.14)$ & $(0.00)$ & $(0.13)$ & $(0.25)$ & $(0.14)$ & $(0.00)$ & $(0.14)$ \\
\hline \multirow[t]{2}{*}{ Leverage $_{\mathrm{t}-1}$} & 0.000 & $0.000^{*}$ & -0.003 & $0.000 * *$ & 0.000 & 0.000 & -0.003 & 0.000 \\
\hline & $(0.38)$ & $(0.07)$ & $(0.44)$ & $(0.02)$ & $(0.41)$ & $(0.26)$ & $(0.45)$ & $(0.19)$ \\
\hline \multirow[t]{2}{*}{$\operatorname{SIZE}_{\mathrm{t}-1}$} & $0.007^{* * *}$ & $0.004^{* *}$ & $0.005^{* *}$ & $0.003^{* *}$ & $0.007^{* * *}$ & $0.003^{* *}$ & $0.005^{*}$ & $0.003^{*}$ \\
\hline & $(0.00)$ & $(0.01)$ & $(0.04)$ & $(0.04)$ & $(0.00)$ & $(0.05)$ & $(0.08)$ & $(0.05)$ \\
\hline \multirow[t]{2}{*}{$\mathrm{SEO}_{\mathrm{t}-1}$} & -0.000 & 0.000 & -0.001 & 0.000 & -0.000 & 0.000 & -0.001 & 0.000 \\
\hline & $(0.81)$ & $(0.31)$ & $(0.26)$ & $(0.36)$ & $(0.79)$ & $(0.42)$ & $(0.21)$ & $(0.51)$ \\
\hline \multirow[t]{2}{*}{$\mathrm{AGE}_{\mathrm{t}-1}$} & $-0.004^{* * *}$ & $-0.005^{* * *}$ & $-0.005^{* * *}$ & $-0.005^{* * *}$ & $-0.004^{* * *}$ & $-0.005^{* * *}$ & $-0.005^{* * *}$ & $-0.005^{* * *}$ \\
\hline & $(0.00)$ & $(0.00)$ & $(0.00)$ & $(0.00)$ & $(0.00)$ & $(0.00)$ & $(0.00)$ & $(0.00)$ \\
\hline \multirow[t]{2}{*}{ INTERCEPT } & -0.072 & 0.021 & -0.041 & 0.048 & $-0.078^{*}$ & 0.028 & -0.024 & 0.033 \\
\hline & $(0.10)$ & $(0.62)$ & $(0.51)$ & $(0.25)$ & $(0.08)$ & $(0.45)$ & $(0.70)$ & $(0.41)$ \\
\hline YEAR & YES & YES & YES & YES & YES & YES & YES & YES \\
\hline
\end{tabular}




\begin{tabular}{|c|c|c|c|c|c|c|c|c|}
\hline INDUSTRY & YES & YES & YES & YES & YES & YES & YES & YES \\
\hline $\mathrm{N}$ & 1803 & 1999 & 1016 & 1883 & 1756 & 1931 & 997 & 1853 \\
\hline adj. R-sq & 0.19 & 0.26 & 0.28 & 0.27 & 0.19 & 0.27 & 0.28 & 0.27 \\
\hline
\end{tabular}


Table 17 Regression results for the impact of corruption events on firms' post-M\&A performance in SOEs.

This table presents the regression results for the impact of corruption events on firms' post-M\&A performance in SOEs. The dependent variable is short-term post-M\&A performance measured by CARs for three-day, five-day and 11-day windows (CAR $(-1,1)$, CAR $(-2,2)$ and CAR $(-5,5))$ and longer-term post-M\&A long-term market performance measured by buy and hold stock returns for oneyear, two-year and three-year windows (BHAR1, BHAR 2 and BHAR3). 'CORRUPTION' is a dummy variable that is equal to one if a firm is a related firm, and zero otherwise. 'POST' is a dummy variable that is equal to one if the observation is obtained after the year of the corruption event, otherwise zero. 'CORP*POST' is the interaction between 'CORRUPTION' and 'POST'. Control variables are defined in Appendix B and the regression is clustered by firms. Standardized beta coefficients; p-values in parentheses. *, **, *** represent significance at $10 \%, 5 \%$ and $1 \%$ levels, respectively.

\begin{tabular}{|c|c|c|c|c|c|c|}
\hline & CAR $(-1,1)$ & CAR $(-2,2)$ & CAR $(-5,5)$ & BHAR1 & BHAR2 & BHAR3 \\
\hline \multirow[t]{2}{*}{ CORRUPTION } & 0.002 & 0.016 & 0.021 & -0.173 & -0.151 & 0.241 \\
\hline & $(0.85)$ & $(0.35)$ & $(0.35)$ & $(0.32)$ & (0.69) & $(0.60)$ \\
\hline \multirow[t]{2}{*}{ POST } & 0.013 & 0.018 & 0.012 & 0.064 & 0.447 & 0.509 \\
\hline & $(0.22)$ & $(0.20)$ & $(0.50)$ & $(0.62)$ & $(0.32)$ & $(0.17)$ \\
\hline \multirow[t]{2}{*}{ CORP*POST } & -0.014 & -0.027 & -0.030 & 0.248 & 0.041 & -0.205 \\
\hline & $(0.43)$ & $(0.27)$ & $(0.33)$ & $(0.24)$ & $(0.93)$ & $(0.71)$ \\
\hline \multirow[t]{2}{*}{ RELATIVE SIZE } & $0.047 * * *$ & $0.077 * * *$ & $0.069 *$ & -0.328 & -0.788 & 0.396 \\
\hline & $(0.00)$ & $(0.00)$ & $(0.09)$ & $(0.11)$ & $(0.31)$ & $(0.59)$ \\
\hline \multirow[t]{2}{*}{ CASH PAYMENT } & $-0.080 * * *$ & $-0.091 * * *$ & $-0.094 * *$ & $-0.530 * *$ & -0.995 & -0.275 \\
\hline & $(0.00)$ & $(0.00)$ & $(0.01)$ & $(0.03)$ & $(0.13)$ & $(0.54)$ \\
\hline \multirow[t]{2}{*}{ SIZE } & $0.007^{*}$ & $0.010^{*}$ & 0.009 & $-0.154^{* *}$ & -0.518 & $-0.621 *$ \\
\hline & $(0.07)$ & $(0.07)$ & $(0.24)$ & $(0.05)$ & $(0.12)$ & $(0.06)$ \\
\hline \multirow[t]{2}{*}{$\mathrm{Q}$} & 0.004 & 0.005 & 0.007 & 0.043 & 0.308 & 0.355 \\
\hline & $(0.36)$ & $(0.40)$ & $(0.42)$ & $(0.40)$ & $(0.16)$ & $(0.24)$ \\
\hline \multirow[t]{2}{*}{ OPCFTA } & 0.059 & 0.061 & 0.070 & $1.138^{* *}$ & -3.983 & -3.207 \\
\hline & $(0.22)$ & $(0.35)$ & (0.39) & $(0.01)$ & $(0.27)$ & $(0.16)$ \\
\hline \multirow[t]{2}{*}{ LEVERAGE } & -0.010 & -0.022 & $-0.108 * * *$ & $1.489 *$ & 5.981 & 7.646 \\
\hline & $(0.67)$ & $(0.43)$ & $(0.01)$ & $(0.10)$ & $(0.17)$ & $(0.13)$ \\
\hline \multirow[t]{2}{*}{ BOARDSIZE } & -0.003 & -0.004 & -0.004 & -0.002 & 0.087 & 0.092 \\
\hline & $(0.11)$ & $(0.12)$ & $(0.34)$ & $(0.94)$ & $(0.29)$ & $(0.28)$ \\
\hline \multirow[t]{2}{*}{ BOARDIND } & -0.117 & -0.113 & -0.109 & -0.245 & 2.164 & 0.127 \\
\hline & $(0.15)$ & $(0.21)$ & $(0.33)$ & $(0.66)$ & $(0.38)$ & $(0.95)$ \\
\hline \multirow[t]{2}{*}{ OWNERSHIP } & -0.138 & -0.402 & -1.386 & -0.468 & 29.443 & 13.895 \\
\hline & $(0.80)$ & $(0.72)$ & $(0.21)$ & $(0.94)$ & $(0.21)$ & $(0.26)$ \\
\hline \multirow[t]{2}{*}{ INTERCEPT } & 0.033 & 0.016 & 0.055 & $3.708^{* * *}$ & $8.109 *$ & $7.812^{*}$ \\
\hline & $(0.66)$ & $(0.88)$ & $(0.70)$ & $(0.00)$ & $(0.06)$ & $(0.06)$ \\
\hline YEAR & YES & YES & YES & YES & YES & YES \\
\hline INDUSTRY & YES & YES & YES & YES & YES & YES \\
\hline $\mathrm{N}$ & 419 & 419 & 419 & 401 & 324 & 243 \\
\hline adj. R-sq & 0.24 & 0.23 & 0.14 & 0.19 & 0.19 & 0.30 \\
\hline
\end{tabular}


Appendix A. A list of corruption events involving high-level bureaucrats in China from 2005 to 2011

\begin{tabular}{|c|c|c|c|}
\hline Name & Announcement date & Province & Duty \\
\hline Zhang Enzhao & 15 March 2005 & Bank & Chairman of China Construction Bank, member of Central Committee for Discipline Inspection \\
\hline Wang Youjie & 28 August 2005 & Henan & Vice-Chairman of NPC in Henan province \\
\hline Huang Songyou & 15 October 2005 & Central & Vice-President of the Supreme People's Court \\
\hline Zhu Zuoyong & 19 December 2005 & Gansu & Vice-Chairman of the CPPCC in Gansu province \\
\hline Liu Zhihua & 9 June 2006 & Beijing & Vice-Governor of Beijing \\
\hline He Minxu & 22 June 2006 & Anhui & Vice-Governor of Anhui province \\
\hline Wang Wulong & 13 July 2006 & Jiangsu & Vice-CPC Secretary of Jiangsu Province \\
\hline Pang Jianyu & 15 September 2006 & Shanxi & Vice-Chairman of the CPPCC in Shanxi province \\
\hline Chen Liangyu & 24 September 2006 & Shanghai & Secretary of CPC in Shanghai \\
\hline Liu Weiming & 22 January 2007 & Guangdong & Vice-Governor of Guangdong province, Vice-Chairman of the CPPCC in Guangdong Province \\
\hline Du Shicheng & 18 April 2007 & Shandong & Vice-CPC secretary of Shandong Province \\
\hline Song Pingshun & 3 June 2007 & Tianjin & Vice-CPC secretary of Tianjin \\
\hline Chen Shaoyong & 8 August 2008 & Fujian & Secretary-general of the CPC in Fujian province \\
\hline Wang Huayuan & 16 April 2009 & Zhejiang & Secretary of CPC in Zhejiang province \\
\hline Chen Shaoji & 24 April 2009 & Guangdong & Chairman of CPPCC in Guangdong province \\
\hline Pi Qiansheng & 17 June 2009 & Tianjin & Member of Standing Committee of CPC in Tianjin \\
\hline Song Yong & 13 October 2009 & Liaoning & Vice-Chairman of NPC in Liaoning province \\
\hline Li Tangtang & 15 October 2009 & Ningxia & Vice-Governor of Ningxia Municipality \\
\hline Huang Yao & 24 October 2009 & Guizhou & Chairman of the CPPCC in Guizhou province \\
\hline Sun Shuyi & 17 December 2009 & Shandong & Chairman of the CPPCC in Shandong province \\
\hline Liu Jiameng & 3 April 2010 & Zhejiang & Vice-Chairman of NPC in Zhejiang province \\
\hline Zhang Jiameng & 3 April 2010 & Zhejiang & Vice-Chairman of NPC in Zhejiang province \\
\hline Song Chenguang & 10 July 2010 & Jiangxi & Vice-Chairman of the CPPCC in Jiangxi province \\
\hline Liu Zhuozhi & 15 December 2010 & Neimengguo & Vice-Governor of Neimengguo Municipality \\
\hline Tian Xueren & 5 November 2011 & Jilin & Member of Standing Committee of CPC Jilin, Executive Vice-Governor of Jilin Province \\
\hline Huang Sheng & 24 November 2011 & Shandong & Vice-Governor of Shandong province \\
\hline Sun $\mathrm{Yu}$ & November 2007 & Guangxi & Vice-Governor of Guangxi Zhuang Autonomous Region \\
\hline Zhu Zhigang & October 2008 & Central & Deputy Finance Minister \\
\hline
\end{tabular}




\section{Appendix B Variable definition}

\section{Variable name}

Related firm dummy (CORRUPTION)

Post event dummy (POST)

Merger and acquisition dummy (MA)

Bureaucrat's jurisdiction dummy (JURISDICTION)

3-days CARs (CAR_1)

5-days CARs (CAR_2)

11-days CARs (CAR_5)

One year buy and hold return (BHAR1)

Two years buy and hold return (BHAR2)

Three years buy and hold return

(BHAR3)

Takeover premium (PREMIUM1)

Takeover premium (PREMIUM2)

Local M\&As dummy (LOCAL)

State owned target dummy (Target SOE)

External financing dummy (External

Financing)

Capital expenditure (CAPEXTA)

Firm size (SIZE)

Tobin's Q (Q)

Return on equity (ROE)

Operation cash flow (OPCFTA)

\section{Detailed definition}

The dummy variable equals 1 if a firm is a related firm and 0 otherwise.

The dummy equals 1 if the observation is obtained after the year of the corruption event, otherwise 0 .

The dummy equals 1 if the firm announced a merger and acquisition, and 0 otherwise.

The dummy equals 1 if the firms locate in the corrupt bureaucrats' jurisdictions, and 0 otherwise.

The cumulative abnormal return over a three-day event window from one day before the M\&A announcement to one day after the announcement.

The cumulative abnormal return over a five-day event window from two days before the M\&A announcement to two days after the announcement.

The cumulative abnormal return over an 11-day event window from five days before the M\&A announcement to five days after the announcement.

The one-year post-M\&A buy and hold return.

The two-year post-M\&A buy and hold return.

The three-year post-M\&A buy and hold return.

The ratio of trading value of the target on the estimated value minus one.

The natural logarithm of the difference between trading value of the target and the target estimated value.

The dummy equals 1 if the firm acquires a local target, and 0 otherwise.

The dummy equals 1 if the target firm is controlled by the state.

The dummy equals 1 if the M\&A deal is financed externally by bank loan, corporate bonds and shares, and 0 otherwise.

The ratio of cash payments for fixed assets, intangible assets and other long-term assets from the cash flow statement less the cash receipts from selling these assets to the total assets.

The natural logarithm of book value of total assets.

Market value/replacement value.

Net profit/total equity.

Total operation cash flow scaled by total assets. 
Leverage ratio (LEVERAGE)

Board size (BOARDSIZE)

Board independent (BOARDIND)

Manager's ownership (OWNERSHIP)

Relative size (RELATIVE SIZE)

Cash financed M\&A (CASH

PAYMENT)

Long term connection dummy 1

(Connection established one year before)

Long term connection dummy 2

(Connection established two years

before)

Long term connection dummy 3

(Connection established three years

before)

Corruption index dummy (Corruption

Index)

Government support industry dummy

(Government Support)
The ratio of total debt to total assets

The total number of members on the board of directors.

The ratio of the number of independent board members to the total number of board members.

The ratio of managers' shareholding to the total shares outstanding

The ratio of the acquisition trading value to acquiring firm's total assets.

The dummy variable equals 1 if the merger and acquisition are financed entirely by cash and 0 otherwise.

The dummy equals 1 if the deals announced by firms that establish connections with corrupt bureaucrats one year before the announcement of M\&As, and 0 otherwise (Variable for dividing Subsamples).

The dummy equals 1 if the deals announced by firms that establish connections with corrupt bureaucrats two year before the announcement of M\&As, and 0 otherwise (Variable for dividing Subsamples).

The dummy equals 1 if the deals announced by firms that establish connections with corrupt bureaucrats three year before the announcement of M\&As, and 0 otherwise (Variable for dividing Subsamples).

The dummy equals 1 if the firm located in the province has corruption index that is higher than the sample median value, and 0 otherwise (Variable for dividing Subsamples).

The dummy equals 1 if the firm operates in a supported industry outlined in the 11th five-year plan in a particular year, and 0 otherwise (Variable for dividing Subsamples). 